\title{
Technology innovation: advancing capacities for the early detection of and rapid response to invasive species
}

\author{
Barbara Martinez • Jamie K. Reaser • Alex Dehgan • Brad Zamft • \\ David Baisch • Colin McCormick • Anthony J. Giordano • Rebecca Aicher • \\ Shah Selbe
}

Received: 3 November 2019/Accepted: 3 November 2019/Published online: 31 December 2019

(C) The Author(s) 2019

\begin{abstract}
The 2016-2018 National Invasive Species Council (NISC) Management Plan and Executive Order 13751 call for US federal agencies to foster technology development and application to address invasive species and their impacts. This paper complements and draws on an Innovation Summit, review of advanced biotechnologies applicable to invasive species management, and a survey of federal agencies that respond to these high-level directives. We provide an assessment of federal government capacities for the early detection of and rapid response to invasive species (EDRR) through advances in technology
\end{abstract}

B. Martinez $(\bowtie) \cdot$ A. Dehgan · B. Zamft ·

D. Baisch - C. McCormick

Conservation X Labs, 1066 31st St. NW, Washington,

DC 20007, USA

e-mail: Barbara@conservationxlabs.org

J. K. Reaser

Center for Large Landscape Conservation, $303 \mathrm{~W}$

Mendenhall St \#4, Bozeman, MT 59715, USA

A. J. Giordano

The Society for the Preservation of Endangered

Carnivores and Their International Ecological Study

(S.P.E.C.I.E.S.), P.O. BOX 7403, Ventura, CA 93006,

USA

R. Aicher

Silver Spring, MD, USA

S. Selbe

Conservify, 1933 South Broadway, Suite 1160,

Los Angeles, CA 90007, USA application; examples of emerging technologies for the detection, identification, reporting, and response to invasive species; and guidance for fostering further advancements in applicable technologies. Throughout the paper, we provide examples of how federal agencies are applying technologies to improve programmatic effectiveness and cost-efficiencies. We also highlight the outstanding technology-related needs identified by federal agencies to overcome barriers to enacting EDRR. Examples include improvements in research facility infrastructure, data mobilization across a wide range of invasive species parameters (from genetic to landscape scales), promotion of and support for filling key gaps in technological capacity (e.g., portable, field-ready devices with automated capacities), and greater investments in technology prizes and challenge competitions.

Keywords Control - Detection - Early detection and rapid response $($ EDRR $) \cdot$ Eradication $\cdot$ Information management · Innovation · Invasive species ·

Technology

\section{Introduction}

Invasive species are a major threat to biosecurity (Meyerson and Reaser 2003), adversely impacting the economy (Bradshaw et al. 2016), natural and cultural resources (Simberloff et al. 2013; Drake et al. 2016; 
Young et al. 2017), infrastructure (Invasive Species Advisory Committee 2016; Connelly et al. 2007), agricultural production (Bradshaw et al. 2016), and human health (Bradshaw et al. 2016; Young et al. 2017). In the United States, the economic damages and control costs of invasive species have been estimated to total more than $\$ 100$ billion per year (Pimentel et al. 2005). Unless we are able to develop and apply more effective solutions, biological invasions and their impacts are expected to increase concurrently with growth in trade, travel, and transport (Mack et al. 2000; Reaser and Waugh 2007; Seebens et al. 2017).

Recognizing the need to innovate solutions to seemingly intractable invasive species problems, the US government's 2016-2018 National Invasive Species Council (NISC) Management Plan (NISC 2016) and Executive Order 13751 (Executive Office of the President 2016) call for federal agencies to foster technology development and application. Responses to these directives have included an Innovation Summit (Conservation X Labs 2017a, b) and a review of advanced biotechnologies (Invasive Species Advisory Committee 2017). This paper is the response to the management plan goal to assess the capacity of the federal government to improve the early detection of and rapid response to invasive species (EDRR) through advances in technology application (NISC 2016).

Reaser et al. (2019a, this issue) define EDRR as a guiding principle for minimizing the impact of invasive species in an expedited yet effective and cost-efficient manner, where "detection" is the process of observing and documenting an invasive species and "response" is the process of reacting to the detection once the organism has been authoritatively identified and response options assessed. Eradication is the ideal outcome of invasive species detection and, due to the self-perpetuating nature of invasive species, there is a narrow window of opportunity for success. The larger the population and area it covers, the greater the likelihood that response options will no longer be feasible (Simberloff 2003).

Consistent with the management plan directive, the information presented in this paper reflects the findings of a survey of US government capacity for EDRR implementation (Reaser et al. 2019a and associated supplemental information, this issue), outputs of the Innovation Summit (Conservation X Labs 2017a, b), a review of recent literature on technology advancement for invasive species applications (e.g., Kamenova et al. 2017), and our direct experience working with technology innovators. We focus on emerging technologies and their applications that, if adapted and scaled as needed to specific contexts, could enhance national EDRR capacity.

Although much of the assessment addresses technologies already or soon to be available, we also explore opportunities to improve technological effectiveness and cost-efficiencies. We conclude the paper with key findings relevant to improving EDRR technological capacities with a view toward building national EDRR capacity. The terminology used and the organization of the paper is consistent with the EDRR framework presented by Reaser et al. (2019a, this issue), where technology is defined as the outputs of mental and physical effort, including tools and machines, intended to serve a societal value. Given limited budgets and other constraints, there is a need to use technologies to improve the effectiveness and cost-efficiency of actions taken at any point in the EDRR process. We focus on technological needs and approaches to improving information support, detection, identification, and response options.

\section{Technology advancement}

Investments in technology innovation are demonstrating that seemingly insurmountable invasive species challenges can be overcome with substantial returns on investment. Although the current toolbox for addressing invasive species is incomplete and inadequate in many cases, new technologies are emerging, cross-over applications are being found for existing technologies (hereafter referred to as dual-use technologies), and multi-technology approaches are proving effective for particularly complicated and largescale problems (Conservation X Labs 2017a).

There are clear opportunities for government leadership in technology innovation. Speakers at the Innovation Summit identified the following as federal agency roles and responsibilities for advancing technologies to improve invasive species prevention, eradication, and control (Conservation X Labs 2017a):

- Communicating the severity of the invasive species issue and the need for technology 
innovation to address pressing invasive species challenges.

- Undertaking the scientific research necessary for technology advancement.

- Catalyzing and incentivizing technology innovation and dual-use technology.

- Enabling innovators to reach proof of concept and implement projects on meaningful scales, potentially producing new industries and jobs in the process.

- Creating, advancing, and maintaining the regulatory frameworks necessary for technology development and application.

- Facilitating international cooperation and development assistance, particularly in the areas of information and technology sharing, technology research and application, and the development of relevant legal frameworks.

- Applying technologies to prevent entry, increase detection, improve response to potential invasive species before they have a chance to cause harm, and to eradicate and control those invasive species that have already established.

In the context of EDRR, federal agencies and their partners need to develop or adapt technologies to be applicable in diverse contexts at varying scales while being time efficient and cost-effective. This will require better incentives for technological innovation and building support within broader social and regulatory frameworks. When applying any technology in the context of EDRR, decision makers and invasive species practitioners need to take the following points into consideration: (1) technology development and application is governed by policies and regulations that may foster or hinder EDRR efforts (BurgosRodríguez and Burgiel 2019, this issue) and (2) social acceptance ("social license") of technologies changes with time and locality and is necessary for enacting EDRR (Kendal and Ford 2017, 2018; van Putten et al. 2018). Privacy and private property rights are of increasing concern for surveillance (Takahashi 2012; McNeal 2016), while advances in genetic technologies as response measures have raised concerns from the public and professional scientists (http://www. synbiowatch.org/gene-drives, accessed 14 February 2019).

Kamenova et al. (2017) provided a comprehensive overview of traditional and emerging technologies for addressing invasive species. Below we build on this review by highlighting technologies and technological needs that are particularly important to US government agencies, as identified through the Innovation Summit (Conservation X Labs 2017a, b) and our assessment of federal capacities for implementing EDRR. Examples of federal agency initiatives to develop, test, and apply emerging technologies to address invasive species are provided throughout this paper. Some of the most promising opportunities for advancing the federal EDRR toolkit may come from agencies that do not have programs focused on invasive species; technologies originally developed for military, intelligence, and human health applications may have dual-use applications for invasive species detection or response. Further information on these federal roles and associated programs is available in the Innovation Summit reports (Conservation X Labs 2017a, b).

\section{Information Inputs}

Accurate, accessible, up-to-date information is necessary to support every aspect of EDRR. Reaser et al. (2019b, this issue) and Wallace et al. (2019, this issue) broadly focus on federal capacities for information management in the EDRR context. We thus limit our presentation to technologies for enhancing information management.

Referring to the EDRR system outlined in Reaser et al. (2019a), target analysis is a strategic approach to evaluating the likelihood of detecting invasive species at a specific locality and time, using a particular method and/or technologies (Morisette et al. 2019, this issue), and risk screening is the rapid characterization of the types and degree of risks posed by a population of non-native species in a particular spatio-temporal context (Meyers et al. 2019, this issue). Both of these EDRR components draw information from other analytical approaches (e.g., horizon scanning; Sutherland et al. 2011; 2013; Roy et al. 2014b) which benefit from sufficient quantitative data. Thus, there is a substantial need for the increased collection of and access to non-native species data, as well as automated approaches to managing and analyzing big datasets (Reaser et al. 2019b, this issue).

Artificial intelligence (AI) is the ability of machines to acquire and apply information, in contrast to the intellectual capacity of humans and other animals. 
Machine learning, an aspect of AI, is a process in which computers can be programmed to apply statistical techniques that enable them to become "selftaught" as they analyze data. This creates a selfimproving analytical platform that increases in reliability over time. Machine learning can be used to verify the accuracy of species occurrence data (e.g., identifying data points outside the norm which may be errors), resulting in more cost-efficient data management and accurate information going into decision support tools (e.g., detecting crop pests; Behmann et al. 2015). The Western Governors Association is currently working with Google and other partners to develop an AI-based tool for cleaning non-native species occurrence datasets (B. Whitacre, pers. comm).

Social media, a set of cost-efficient and readily accessible technology platforms, can be used to augment the invasive species biology and occurrence data necessary to inform detection and response strategies. For example, Daume (2016) found that an analysis of Twitter posts about a few specific invasive species was a strong indicator for important life cycle activities (e.g., adult emergence for emerald ash borer [Agrilus planipennis]), as well as a method of assessing public communications and perceptions of invasive species and their management. Researchers have used online geotagged photo sharing sites, like Flickr and Panoramio, to mine for data on ecosystem services (Figueroa-Alfaro and Tang 2017).These datasets could also provide additional geographic granularity for some invasive species.

Because geographic information systems (GIS) have the ability to gather, manage, analyze, and enable visualization of many types of spatio-temporal data, they are now a standard technology for natural resource managers (Wing and Bettinger 2008). In the context of EDRR, they provide a means of mapping species occurrence data in conjunction with a wide variety of environmental parameters (e.g., vegetation, moisture, temperature) so that relationships can be evaluated, and species distribution models developed (Guisan and Thuiller 2005; Gallo and Waitt 2011). In response to our survey of federal needs, the Department of the Interior's (DOI) US Fish and Wildlife Service (USFWS) indicated the need for a GIS database to support EDRR. The database would include multiple layers of information relevant to the detection of invasive species (e.g., biological parameters), as well as relevant information on potential recipient ecosystems (e.g., habitat suitability or disturbance parameters). The DOI National Park Service (NPS) acknowledged a similar need, suggesting that GIS systems have the ability to distribute alerts when invasive species are detected, update maps in a timely manner, and show the distribution of invasive species relative to federal resources (e.g., National Parks) so that surveys can be prioritized.

Complementary to GIS, remote sensing and satellite imagery can contribute to invasive species management. The National Aeronautics and Space Administration (NASA) responded to the survey to highlight how satellite products are used to document invasive species distributions (e.g., via habitat classification and species distribution modelling), spread (e.g., through time-series analysis), and ecology (e.g., distributional associations between species or environment). In addition, satellite products can be used to predict how invasive species will be impacted by future conditions by analyzing current distributional associations with climate or environment variables and applying those relationships to projected future models. Such tools can be combined with high temporal and spatial resolution information from the unmanned aerial vehicles, remotely operated vehicles, and nanosatellites described below.

\section{Detection and identification}

Invasive species may be difficult to detect, especially when first introduced because the founding population size and density are often low or the organisms may be small bodied and/or cryptic, enter landscapes that are complex and/or remote, and be unknown to observers (Morisette et al. 2019, this issue). In this section we provide an overview of technologies that can be used to increase the likelihood and efficiency of invasive species detection, as well as the rate and accuracy of invasive species identification. In the context of EDRR, the ability to detect and identify organisms in a near-simultaneous manner is ideal, although identification should also be considered tentative until confirmed by a taxonomic expert (authoritative identifier). Additional discussion on federal needs for taxonomic capacity, as well as examples of identification technologies are provided in Lyal and Miller (2019, this issue). 
Internet-based detection

Internet commerce (hereafter e-commerce) is a vital part of the US economy that has experienced substantial growth in recent years. A portion of this activity includes the sale and trade of living organisms, some of them are invasive species or organisms associated with invasive species. A number of federal entities have jurisdiction over aspects of e-commerce and, in 2014, the National Invasive Species Council's Invasive Species Advisory Committee (ISAC) recommended these agencies (esp. US Department of Agriculture [USDA], USFWS, and the Department of Homeland Security [DHS]) expand the use of web crawlers to detect invasive species moving through e-commerce (ISAC 2014). A "web crawler" is a program or automated script which "scrapes" the World Wide Web for specific information (based on keywords or codes) in a methodical, automated manner. Suiter and Sferrazza (2007) reported on an Invasive Species Internet Monitoring System (ISIMS) being used by USDA's Animal and Plant Health Inspection Service [APHIS], Plant Protection and Quarantine [PPQ] and the Smuggling, Interdiction and Trade Compliance [SITC] program to search for websites selling regulated insects, weeds, mollusks, fruits and vegetables, and for animals and animal products that have the potential to carry highly pathogenic avian influenza. To the best of our knowledge, ISIMS is now focused on a limited number of plant pests affecting major agricultural commodity crops. Coupling web crawler and machine learning technologies could produce powerful tools for detecting invasive species prior to their potential entry into natural or agricultural environments.

The Internet of Things (IoT) phenomenon refers to the use of internet-connected sensors (visual, chemical, acoustic, and biological) to help make decisions or increase efficiency within our homes and cities based on near-real-time data collection. The adaptation of this hardware and software into environmental protection is being explored in projects globally (Guo et al. 2015; Hart and Martinez 2015). Readily available low-cost sensor components and microcontrollers (e.g., Arduino, Adafruit, Raspberry Pi) are improving and expanding invasive species detection capacities. For example, a Montana-based company, AIS Solutions, is testing a "geo-fencing" technology for more accurate monitoring and tracking of watercraft to prevent the spread of zebra and quagga mussels. The technology includes relatively inexpensive electronics outfitted on recreational watercraft, including a small, waterproof battery, and solar-powered geographic positioning system (GPS) or electronic logging device (ELD). The winning entry in the US Department of State's (DOS) 2016 Fishhackathon (a digital technology coding competition focused on marine issues) was "Great Lakes Savior," a solution that leveraged basic scientific sensors, an IoT infrastructure, and spawning models to attempt to predict the hatching period of invasive carp in the Great Lakes based on water temperature.

There are online communities and open innovation sites dedicated to facilitating the merger of AI and big data analytics (e.g., Banerji et al. 2010; Beaumont et al. 2014; Swanson et al. 2016). Crowdsourcing through platforms like eBird (Sullivan et al. 2014) and iNaturalist (Van Horn et al. 2018) can also accelerate the identification of large numbers of complex images (Santana et al. 2014) that may contain invasive species. At the time of writing, iNaturalist has used its global set of identified photos of biodiversity to train computer vision to suggest identifications for more than 24,000 species (C. Seltzer, pers. comm). Because most invasive species originate outside of the United States, incorporation of a global dataset offers clear advantages; species that are common elsewhere in the world may be detected more readily in new areas if they are suggested by the computer vision model. An example of this recently occurred in Ontario where the invasive box tree moth (Cydalima perspectalis) appears to have been recorded for the first time in North America (https://www.inaturalist.org/blog/ 18683-an-invasive-moth-is-recorded-in-ontario-canadafor-the-first-time-observation-of-the-week-9-9-18, accessed 30 October 2019).

\section{Visual detection}

Traditional approaches to the visual detection of invasive species include observation with the naked eye, binoculars, spotting scopes, and microscopes. The effectiveness of these relatively low tech and low-cost approaches could be improved using advanced analytical tools for target analysis (Morisette et al. 2019, this issue). For example, DOI's US Geological Survey (USGS) Fort Collins Science Center (FORT) is optimizing search efforts for the invasive brown tree 
snake (Boiga irregularis; Klein et al. 2015) in Guam by evaluating the pace that transects are searched. Preliminary findings indicate that visual searches walked at a faster pace $(1.32 \mathrm{~km} / \mathrm{h})$ than current pace $(0.44 \mathrm{~km} / \mathrm{h})$ yield $63 \%$ more snakes per unit time.

There are more than 7.5 billion mobile phone subscriptions around the world, including 3.9 billion smartphone subscriptions (Ericsson 2016). Smartphones today contain multiple sensors (Lane et al. 2010), including microphones, cameras, altimeters, accelerometers, barometers, gyroscopes, proximity sensors, compasses, Bluetooth network devices, and GPS sensors. Smartphones are thus enabling real-time linkages between field-based visual observations and internet-based identification, reporting, and mapping. In addition to the iNaturalist program described in the previous section, federal agencies and others are using the Early Detection and Distribution Mapping System (EDDMapS; https://www.eddmaps.org, accessed 30 October 2019) to identify and report the locality of invasive species from the field. For example, the USGS Great Lakes Science Center is developing a Phragmities Adaptive Management Framework that includes EDDMapS integration (http:// greatlakesphragmites.net/pamf, accessed 30 October 2019).

Advances in the application of light-based technologies are also making some invasive species more readily detectable and identifiable. For example, USGS FORT and the National Wildlife Health Center (NWHC) have developed an ultraviolet light to detect an invasive microscopic fungi (Pseudogymnoascus destructans) that causes the devastating white-nose syndrome in hibernating bats. Similarly, the US Environmental Protection Agency (EPA) has worked with various partners to develop approaches to visually distinguish between algae, cyanobacteria, and golden algae (Prymnesium parvum). Researchers use a blue fluorescent light (around $480 \mathrm{~nm}$ ) and green fluorescent light (around $545 \mathrm{~nm}$ ) to excite organisms and distinguish between algae and cyanobacterial based on the specific autofluorescence of their photosynthetic pigments. The presence of the organism is then confirmed using the Prism and Reflector Imaging Spectroscopy System.

Opportunities for visual detection can also be enhanced through the use of traps, attractants, algorithms, and various sensors. Traditional trapping approaches are discussed later under the Response
Technologies section. Here we focus on camera traps, small devices that utilize motion sensors to remotely capture digital images (photo or video) (Swann et al. 2010; Burton et al. 2015). Camera traps work particularly well for detecting large-bodied, mobile, and cryptic species that are otherwise challenging to detect in remote or rough terrain (Linkie et al. 2013; Sollmann et al. 2014). Technological advances in camera trap technology include "smart" capabilities, such as 360 degrees image capture, machine vision (see Martinez et al. 2018), sensors that facilitate automatic object tracking once a species is recognized, and the ability to report species in real-time. Some of these functions already exist in consumer drones and camera traps (Ramsey 2012) and are being applied in federal programs. For example, the USGS is working with Conservation Metrics, Inc. to develop machine vision algorithms from existing camera trap images of brown tree snakes.

With support from the Department of Energy [DOE], Whooshh Innovations has developed a dualuse fish passage technology that employs real time electronic scanning to identify and manually extract invasive fish when they try to pass a fish barrier. The system is trained to distinguish invasive fish from native fish and direct them into separate tubes; native fish pass through the system into spawning groups and invasive fish are removed from the waterway. It's hoped that advances in machine vision will eventually allow full automation of the system (Conservation X Labs 2017b).

\section{Acoustic detection}

Non-native species that vocalize or otherwise make sound (e.g., chewing) can be detected through environmental audio recordings (Servick 2014). Acoustic detection approaches for birds (Dawson and Efford 2009), bats (O'Farrell et al. 1999), and other animals are well-established (e.g., for aquatic animals see Kessel et al. 2014). However, process efficiencies (cost and time) and identification accuracies would likely be improved by applying AI approaches to information management and data analysis (e.g., for AI applied to bird detection see Stowell et al. 2018 and for bat detection see Mac Aodha et al. 2018).

Technology advancements are enabling acoustic detection of organisms that are far less audible to the human ear. For example, the Stevens Institute of 
Technology, working with DHS Customs and Border Protection (CBP), has used acoustic sensors (piezoelectric sensors, lasers, Doppler vibrometers-also applicable to wood, ultrasound microphones) to monitor rodents and insect pests in grain shipments (Flynn et al. 2016). In laboratory settings, off-the-shelf laser vibrometers detected Asian longhorned beetle larvae (Anoplophora glabripennis) in wood samples (Zorović and Čokl 2014), as well as adult and larval Dermestid beetles (Trogoderma inclusum) and mealworms (Tenebrio molitor) in rice samples (Flynn et al. 2016). Based on these successes, DHS is developing detection tools for use at ports of entry that include both microwave and acoustic sensors (Flynn et al. 2016).

Mosquito detection is another emerging application of acoustic sensors. For example, a program called HumBug is collecting audio recordings of mosquitos to train machine learning algorithms to identify the 3,600 known species of mosquitos based on sound. The goal is to create a program that will notify users (e.g., via smartphones) about the presence of mosquito species in a user's proximity. Alerts such as these could be incorporated into national EDRR programs to enable the rapid detection of invasive mosquitoes and/ or invasive pathogens (e.g., Zika virus) transmitted by mosquito vectors.

Smartphones, which contain microphones and sufficient computational power for acoustic monitoring (Lane et al. 2010), are enabling rapid growth in the population of acoustic detectors. This is particularly true for taxonomic groups (esp. birds) that already garner substantial attention from naturalists and citizen scientists (e.g., bats and loons in Maine; Stockwell and Gallo 2017).

Examples of other federal agency applications of acoustic technologies to detect invasive species include the USGS Great Lakes Science Center (GLSC)'s use of Dual Frequency Identification Sonar (DIDSON) to assess the abundance and migration timing of sea lamprey (Petromyzon marinus) and common carp (Cyprinus carpio) in Great Lakes tributaries. Collaborators at Central Michigan University are developing an automated data processing program. USGS also operates adaptive resolution imaging sonar (ARIS), the next generation of DIDSON, in wetland and other habitats to characterize fish movement and habitat (http://www.soundmetric. som/products/aris-sonars, accessed 30 October 2019).
Chemical detection

Dogs can provide a "low-tech" yet sophisticated approach to the chemical detection of invasive species. Initially used to detect scat and other signs of cryptic endangered species (Reindl-Thompson et al. 2006), detector dogs are now accomplishing numerous other conservation tasks, including detection of birds killed by striking windows and other infrastructure (Homan et al. 2001), illegally trafficked animal parts, and invasive species. Not surprisingly, dogs have been used most frequently and successfully to detect invasive mammals, including feral cats (Felis catus), nutria (Myocastor coypus), and the small Indian mongoose (Herpestes javanicus) (Fukuhara et al. 2010; Kendrot 2011; Glen et al. 2016). Detector dogs have also successfully located a variety of other invasive taxa, including Dreissenid mussels (see http://www.musseldogs.info, accessed 30 October 2019), brown tree snakes, Burmese pythons (Python bivittatus) (Savidge et al. 2011; Avery et al. 2014), insects (Lin et al. 2011; Lee et al. 2014), and even invasive plants (Goodwin et al. 2010). In addition to their use in the field, detector dogs are used to inspect both outgoing and incoming cargo at ports of entry (Vice and Vice 2004).

E-nose devices, engineered biomimics of a dog's nose, are currently used in laboratory settings within the agricultural industry to detect the presence of invasive microbes on crops and other plants, for example (Baietto et al. 2015; Wilson 2013; Jansen et al. 2011; Wilson et al. 2004). There is at least one portable e-nose device on the market (Sensigent's Cyranose e-nose), and a research team at the Swiss Federal Institute of Technology in Zurich (ETH Zurich) is working on a small, low-cost version. Lower cost sensor components and microcontrollers are making it possible to construct and experiment with inexpensive portable e-nose devices (Macías Macías et al. 2013). Portable e-nose devices could be deployed in the field (e.g., attached to drones, at a port of entry) to detect the volatile organic compounds (VOCs) emitted by plants when vegetative tissues are damaged by invasive species (Unsicker et al. 2009).

Advances in nanofabrication (design and manufacture of devices with dimensions measured per nanometer) have permitted the manufacture of highly sensitive nanobiosensors in large volumes at relatively low cost. A nanobiosensor is made of nanomaterials 
that assess biological interactions and translate the output into a readable form using transduction and electromechanical interpretation (Malik et al. 2013). They can act as accurate chemical sensors (Chikkadi et al. 2012). Nanobiosensors have already been developed for the agricultural and veterinary sectors to detect invasive pathogens (fungal, viral, and bacterial) in crops and animals (Lambe et al. 2016; Handford et al. 2014; Chen and Yada 2011). If networked and scaled, nanobiosensors may be able to detect the VOCs emitted by invasive plants, insects, and pathogens over a large area (Afsharinejad et al. 2016). These and other advances in development may provide tools for detecting a wide range of invasive species at ports of entry or in recipient ecosystems.

USGS GLSC researchers are studying sea lamprey pheromones and alarm cues that could be used in a "push-pull" technique to (1) attract sea lampreys to traps, unsuitable spawning habitat, or areas that can be treated with lampricides and (2) deter sea lampreys from entering areas that have optimal spawning habitat or are difficult to treat with lampricides. USGS FORT scientists are experimenting with novel scents sprayed along transects with the goals of drawing brown tree snakes near to increase detection rates and enable more effective response.

\section{Genetic detection}

Numerous molecular diagnostic tools have been developed in recent years for use in clinical settings, and there has been a push to apply similar tools to invasive species management. In particular, there are opportunities to use genomic tools for invasive species biosurveillance (e.g., for managing forest pests; Bilodeau et al. 2018; Roe et al. 2018). The use of deoxyribonucleic acid (DNA) for invasive species identification is well-established (Lyal and Miller 2019, this issue), but limited in application because relatively few species have been genetically sequenced and profiled in open access information systems, including GenBank, the National Institute of Health (NIH) annotated collection of all publicly available gene sequences (Benson et al. 2013), or the other international databases with which GenBank interfaces (https://www.ncbi.nlm.nih.gov/genbank, accessed 30 October 2019). Examples of current and emerging tools for the genetic-based detection and identification of invasive species follow. Those drawn from the federal agencies indicate that applicable research, information management, and technology advances are scattered across numerous programs, some of which may be duplicative with regard to species and approaches being addressed. There are clear opportunities and needs to provide a unified vision for these efforts, establish standards to make research outputs repeatable and readily comparable, and develop a government-wide repository for genomic information on non-native species. The USFS National Genomics Center for Fish and Wildlife Conservation (https://www.fs.fed.us/research/ genomics-center/species-profiles, accessed 30 October 2019) may be appropriate for such a role. Since there are indications that genome size tends to be small for invasive species and measuring genome size is well established and inexpensive (Suda et al. 2014), the repository would ideally facilitate additional analysis of genomic size implications for invasiveness risk by filling data gaps and linking with other relevant information systems (Garcia et al. 2014).

With funding from the USFWS, researchers from Jacksonville State University and King's College London are developing rapid detection protocols and refining molecular techniques for the identification of an invasive freshwater snail, red-rimmed melania (Melanoides tuberculata) and associated trematodes using DNA barcoding, a method of using a short genetic marker in an organism's DNA to identify it as belonging to a particular species. Ultimately, they hope to be able to evaluate the genetic relatedness of populations to determine pathways and dispersion patterns. DNA barcoding has also been used to identify invasive wood-boring beetles in solid wood packaging, thus creating an opportunity to improve the rates of invasive species interception at ports of entry (Wu et al. 2017). Armstrong and Ball (2005) discuss the application of DNA barcodes to biosecurity.

Unfortunately, the current approaches to DNA barcoding are costly, require laboratory analysis, and need substantial time and expertise to analyze samples. The development of portable, field-ready DNA sequencing systems could reduce the costs, training, equipment, and time required for barcode analysis. These systems are becoming increasingly feasible, enabled in part by new devices such as the Oxford Nanopore MinION and nextGen Smidgion and by the International DNA Barcode of Life Library database (http://ibol.org, accessed 30 October 2019; Jain et al. 
2015). Conservation X Labs is developing a low-cost, modular, battery-powered, field-ready device to extract, amplify, and identify DNA barcodes from biological samples (John 2016). The product would make it feasible to use DNA barcoding as a standard tool for the detection of species for which the relevant genetic information had already been catalogued.

Environmental DNA (eDNA) is the DNA of organisms secreted into the environment via feces, mucus, and gametes (an organism's reproductive cells), as well as through shed cells, skin, hair, and decomposing carcasses (Thomsen and Willerslev 2015). It is readily detectable in soil and water samples and can bypass many of the issues inherent in observing or capturing an organism (Foote et al. 2012; Jerde et al. 2011). The specificity and broad contextual application of eDNA makes the approach attractive as an invasive species detection tool (Hinlo et al. 2018; Kamenova et al. 2017).

Multiple US agencies are funding, developing, testing, and applying eDNA techniques to rapidly detect and identify invasive species. For example, the USFWS Conservation Genetics Laboratory in Anchorage, Alaska has developed a species-specific eDNA assay that is being used to test water samples collected by the Alaska Department of Fish and Game for evidence of northern pike (Esox lucius). USFWS Warm Springs, Fish Technology Center is developing and refining eDNA techniques for detection of numerous species, including the crayfish plague agent (Aphanomyces astaci), African jewelfish (Hemichromis bimaculatus), and Asian swamp eel (Monopterus albus). The USFWS has provided funding to the California University of Pennsylvania to develop eDNA protocols for the detection of the rusty crayfish (Orconectes rusticus) in lotic streams. As part of the Great Lakes Restoration Initiative (GLRI) the EPA Cincinnati lab is working with The Nature Conservancy and Hawaii Pacific University to evaluate the applicability of incorporating eDNA metabarcoding into detection programs as a taxonomic identification tool for multiple species simultaneously. Work by the NPS suggests that eDNA analysis may improve our ability to detect invasive species earlier in the invasion process than previously feasible.

Advances in the capacity of systems to sequence eDNA rapidly at high volume could radically advance detection-identification-reporting speeds while reducing labor costs (Taberlet et al. 2012; Reuter et al.
2015). One of the shortcomings of eDNA analysis is that it detects the presence of the target DNA, but the analysis does not distinguish the point of origin of the DNA (Roussel et al. 2015). eDNA has been detected from fish removed from an ecosystem up to 35 days after elimination (Dunker et al. 2016), which makes the assay's high sensitivity a potential limitation due to sample contamination or the removal (or departure) of the organism from the site prior to testing. Traditional detection methods can, and ideally should, be combined with eDNA for results verification (Kamenova et al. 2017).

Field-based biological assays designed to identify species in a short period of time based on genetic material are also showing promise as scalable technologies for invasive species detection and identification. For example, USGS is creating an assay to detect invasive carp based on eDNA via loop-mediated isothermal amplification (LAMP; https://www.usgs. gov/centers/umesc/science/developing-a-portablelamp-assay-detecting-grass-and-black-carp, accessed 30 October 2019). Microsoft's Project Premonition (https://www.microsoft.com/en-us/research/project/ project-premonition/, accessed 30 October 2019), an effort funded by the Department of Defense's Intelligence Advanced Research Projects Activity (IARPA) program, developed AI-based traps to identify and selectively capture mosquitoes. The next step is to remotely detect pathogens carried by the trapped mosquitoes through gene sequencing.

Unmanned aerial vehicles and remotely operated vehicles

Unmanned aerial vehicles (UAVs) and underwater remotely operated vehicles (ROVs) can provide costefficient detection of some invasive species. They are particularly useful for species that are readily detected by sight (e.g., large bodies, distinctive vegetative patterns) and the search needs to proceed over large areas and/or rough terrain that is difficult for humans to directly access. Despite the regulatory and licensing barriers to deploying drones in the United States (Burgos-Rodríguez and Burgiel 2019, this issue; Werden et al. 2015), they are rapidly becoming standard equipment in conservation toolkits.

UAVs and ROVs can be outfitted to carry a variety of cameras and sensors designed to maximize the likelihood of detection (Harwin and Lucieer 2012). 
Some systems are able to collect biological specimens for species analysis. Examples of invasive species detected through the use of drones in combination with image processing include: yellow flag iris (Iris pseudacorus; Baron et al. 2018), invasive grasses (Cenchrus ciliaris and Triodia spp.; Sandino et al. 2018), Burmese pythons (Python bivittatus; Gomes 2017), and silk oak trees (Grevillea robusta; Strohecker 2017).

Drones can also replace aircraft and other vehicles in carrying advanced sensor packages like a laserbased light detection and ranging system similar to radar, known as LiDAR, which have been used to detect invasive plants (Asner et al. 2008; Barbosa et al. 2016) and fish (TerraDaily 2018). Lightweight LiDAR sensors for drones are either already on the market or under development (e.g., LeddarTech and Luminar). In Florida, the Army Corps of Engineers (USACE) is currently using a NOVA/NOVA Block II UAV system, which can carry $15 \mathrm{lb}$, cover 750 acres, and take images at a $3.5 \mathrm{~cm}$ resolution. Geomatics experts have been engaged to help with auto-classification of the aerial imagery collected from UAVs to automatically identify specific objects of interest. For instance, USACE uses auto-classification algorithms to identify invasive grasses.

Although not as readily controlled over large areas, Do-it-Yourself (DIY) kite or balloon mapping can also provide inexpensive site access and high-resolution sensor transport to support invasive species detection via remote imaging. Public Lab has pioneered the use of kite and balloon mapping and created open source software, MapKnitter, to combine aerial images into a georeferenced mosaic (Delord et al. 2015). Because kite and balloon mapping equipment is inexpensive and readily available to the public citizenry, these approaches could greatly facilitate the detection and reporting of invasive species over large areas of private land. They are well suited for EDRR initiatives led by citizen scientists.

\section{Nanosatellites}

Traditional earth observation satellites are costly (e.g., Landsat 8 cost approximately $\$ 900$ million), nonadaptable once constructed, and require a decadeslong development time. More technologically flexible, low-cost nanosatellites (satellites of low mass and size, usually under $500 \mathrm{~kg}$ ) may be useful for detecting invasive species via remote-sensing data in situations in which larger satellites are limited by cost, spatial and/or temporal resolution, and orbital parameters, and drones are limited by battery power, payload, and social acceptance (Selva and Krejci 2012; see Table 4 in Martinez et al. 2018). Nanosatellite constellations can leverage the low costs of the satellites and their launch, coupled with a rapid launch cycle, to allow for rapid evolution of the constellation capacity. One company, Planet, operates a constellation of 149 nanosatellites, enabling three-meter-resolution imagery of the Earth every day (https://www.planet.com, accessed 30 October 2019). By comparison, Landsat 8 provides $30 \mathrm{~m}$ resolution ( $15 \mathrm{~m}$ panchromatic) of the entire planet every 16 days (Roy et al. 2014a). Nanosatellites also have the capacity to harness the rapid evolution of consumer electronics. EarthNow is developing a constellation of satellites to provide realtime on-demand pictures and video of anywhere on the planet (https://earthnow.com, accessed 30 October 2019).

There are some drawbacks to nanosatellite constellations, including small platform size, lower operational powers, and larger data analysis challenges (e.g., calibrating sensors across many individual satellites, ground truthing, and data integration) (Dash and Ogutu 2016). However, well-calibrated instruments managed by federal agencies, like Landsat and MODIS, can complement nanosatellites to overcome some of these issues. Even given these limitations, the potential for landscape-scale monitoring based on frequent, high-spatial-resolution data would be a powerful tool for detecting significant population changes of invasive species across very large regions. Furthermore, NASA's venture class missions, such as Global Ecosystem Dynamics Investigation (GEDI) (https://gedi.umd.edu/, accessed 30 October 2019) and ECOsystem Spaceborne Thermal Radiometer Experiment on Space Station (ECOSTRESS) (https:// eospso.nasa.gov/mission-category/13, accessed 30 October 2019) demonstrate quicker and more nimble federal space-borne programs that can bridge between traditional satellite sensors and nanosatellites. EDRR programs should have access to up-to-date, frequently available remotely sensed data, as high-resolution distribution maps of invasive species are critical to target management of early infestations and to model future invasion risk (Bradley 2014). 
Response technologies

In the context of EDRR, response technologies are needed to facilitate the speed at which eradication and containment can be initiated and fully enacted. They are also needed to broaden the response toolkit, enabling effective and cost-efficient responses to species and in localities that have thus far proven too challenging to address with current approaches.

Many of the technologies discussed in the context of invasive species detection can also facilitate invasive species eradication and containment when used individually or in combination. For example, researchers at the University of Alberta used machine learning to analyze the factors that led to success or failure in 143 attempts to eradicate aquatic invasive species and developed a decision tree for responders in the field to guide their choice of response strategy (Xiao et al. 2018). Campbell et al. (2015) predict that drones, in combination with infrared cameras, preprogrammed night flights, bait delivery mechanisms, and AI data processing, will be widely adopted for invasive rodent eradication programs within the next five years (see also Sandino et al. 2018). Below we provide a brief overview of response tools not previously discussed in this paper.

\section{Mechanical advancements}

Federal agencies and their partners are working to improve traditional approaches to the capture, removal, and exclusion (containment) of invasive animals. Goals include increasing system effectiveness, cost-efficiency, portability, and deployment speed, while minimizing impacts on non-target species. For example, USGS researchers have developed and enhanced traps for brown tree snakes, developed traps for Burmese pythons, designed multi-capture traps for tegu lizards (Salvator merianae), improved capture rates and efficiency for the sea lamprey, and developed attractants that improve Asian carp net captures. Frequently, this work involves a combination of behavior research, modeling, and engineering. Studies of brown tree snake behavior at traps, combined with analytical modeling using a program known as SLITHER, contributed to advances in trap design and strategy for brown tree snakes (Lardner et al. 2017). The National Oceanic and Atmospheric Administration (NOAA) and two non- profit organizations have supported multi-faceted research on a modified lionfish (Pterois spp.) trap that uses a fish-attraction device, allows for deep water control of lionfish, minimizes bycatch, and is easy to transport, deploy, and retrieve. In initial tests, the trap caught more than $75 \%$ of the lionfish it attracted during an 18-day "soak time." Further advancements are in progress (Conservation X Labs 2017b; LieberKotz 2017; Yuzvik et al. 2018).

Fencing can be used to create barriers that limit and/ or direct invasive species movement to increase capture rates. Fences have long been used to successfully control feral pigs and goats. Recently, lessons learned from that work, aided in the construction and operation of the longest cat-proof fence (five miles) in the United States at Hawaii Volcanoes National Park. It is hoped that the fence will prevent cats from accessing the main nesting area of the federally endangered native seabird 'ua'u, or Hawaiian petrel (Ferracane 2016). Virtual fencing can also be created using various non-physical barriers to animal movement. For example, studies of fish sensitivities to electric fields have enabled the USGS GLSC to employ a stream-wide field of pulsed direct current (electric lead) to guide sea lamprey into an underwater trap, enabling the removal of up to $80 \%$ of the animals from free-flowing streams in the Great Lakes Basin.

In the Midwest, the USFWS has innovated a new approach to electro-fishing, a technique developed in the 1930s that delivers underwater electric current that shocks fish (like a stun gun), causing them to float to the surface where they can be readily netted. A specially designed boat-the Magna Carpa-with giant wing-like nets protruding from its sides, cruises large water bodies for Asian carp. Using a higher charge, they can kill and cull the fish. In approximately five minutes, they are able to collect as many as 500 carp, which are later processed into fertilizer (Fronte and Garth 2015).

Robotics, alone or in combination with other technologies, can increase the timeliness and costefficiency of various response measures (Cantrell et al. 2017). Robots provide additional labor for long hours in challenging conditions (e.g., underwater, during inclement weather, at night). Researchers at the Queensland University of Technology created the COTSbot (crown-of-thorns starfish robot), an autonomous robot equipped with machine vision, stereoscopic cameras, and a pneumatic injection arm, to 
identify and kill crown-of-thorns starfish (Acanthaster planci) in the Great Barrier Reef. Envirocart created a diver-assisted technology that cleans invasive species and other debris off the hulls of large vessels in the water and is working on a version that does not require human assistance. These innovations suggest that investments in robotic technology could substantially increase rapid response capacities in a wide range of contexts.

\section{Chemical advancements}

Toxicants Pesticides are one of the most commonly used tools in the invasive species toolkit (Wittenberg and Cock 2001). The need to protect agricultural products has led to the development of numerous toxicants for terrestrial plants and animals, some broad-spectrum, others target-specific. In responding to the federal survey (Reaser 2019, this issue), federal agencies noted that there are substantially fewer pesticides available to address aquatic invasive species and they tend to have substantial shortcomings, including lack of ability to target specific taxonomic groups and the need to apply chemicals throughout the entire water-column, resulting in equal exposures of native and invasive species.

Federal agencies are funding, developing, testing, and applying new toxicants for aquatic invasive species. For example, the USGS Upper Midwest Environmental Research Center (UMESC) is developing a system that allows for targeted delivery of pesticides to kill silver carp (Hypophthalmichthys molitrix) and bighead carp (Hypophthalmichthys nobilis). They are also experimenting with carbon dioxide as a non-selective deterrent to invasive fish passage and for lethal control. The initial work has demonstrated $100 \%$ mortality of silver carp when $\mathrm{CO}_{2}$ is injected under ice. The USGS Columbia Environmental Research Center (CERC) is beginning to develop a piscicide that would affect only black carp (Mylopharyngodon piceus); the work takes advantage of the species' unique feeding behavior and properties of the toxicant.

Marrone Bio Innovations' development of Zequanox, the only selective and environmentally compatible molluscicide commercially available for killing zebra (Dreissena polymorpha) and quagga mussels (Dreissena bugensis), inspired the USGS UMESC to organize an Invasive Mussels Collaborative (IMC; http://invasivemusselscollaborative.net, accessed 30 October 2019), hosted by the Great Lakes Commission. The IMC advances scientifically sound technologies for invasive mussel control. This initiative could serve as a model for managing the development and application of other emerging invasive species technologies.

Federal agencies have also been facilitating rapid advances in treatment technologies for hull fouling over the last decade. The US Coast Guard recently summarized vessel biofouling prevention and management options with an emphasis on technology advancement (US Coast Guard 2015). The current approach to addressing invasive hull fouling organisms is to apply anti-fouling and/or foul-release coatings that disrupt biofilm formation (i.e., attachment capacity). Anti-fouling coatings prevent or deter the settling of biofouling organisms on a surface by the use of leached pesticides, typically cuprous oxide or tributyltin, into the water. The pesticides are either tethered to the coated surface or are released from the surface into the surrounding environment. Foul release coatings present a hydrophobic, low surface energy that minimizes the adhesion of biofouling organisms. Additional work is needed for processes to treat submerged niche areas of ships (e.g., rudders, sea chests) where organisms can find shelter.

Not all of the toxicant advancements have been in the aquatic sector. For example, staff of USDA's National Wildlife Research Center (NWRC) and collaborators have been working together to develop Hog-Gone, a sodium nitrate bait for controlling feral pigs. At high doses, the product reduces the ability of red blood cells to release oxygen to tissues causing organs to fail. Swine are particularly sensitive to sodium nitrate and work is underway to evaluate and minimize non-target effects (Snow et al. 2018).

Toxicant delivery Technological advances are also being made to improve the delivery of existing toxicants. For example, the NPS successfully worked with partners to innovate the delivery of toxicants to black rats (Rattus rattus) via aerial broadcast on Anacapa Island in Channel Islands National Park (Howald et al. 2010). On nearby Santa Cruz Island, they are working with collaborators to eradicate argentine ants (Linepithema humile) using a pesticide delivered in hydrating beads (https://www.nps.gov/ chis/learn/management/ants.htm, accessed 30 October 2019). 
Researchers from USDA NWRC and their colleagues have been developing various approaches to deploying dead neonatal mice baits treated with acetaminophen, which is toxic to the snakes, to reduce brown tree snake populations in forested sites on Guam. The treated mice are individually attached to four-foot-long paper flag streamers and deployed by hand from helicopters or, in recent experimental trials, by a modified air gun. The streamers entangle the treated mice in vegetation above ground level, where they can be consumed by brown tree snakes and are less likely to be consumed by non-target species. The USDA Wildlife Services staff are also developing a Hog-Hopper bait dispenser that limits delivery of HogGone to feral pigs.

Signal disruption Many invasive animals and parasites use chemical signaling to identify food and habitat resources, as well as communicate with others of their species (e.g., to attract mates). Highly targeted pesticides can be used to disrupt these processes. For example, researchers in New Zealand and with the USDA found that the application of multiple types of pheromones led to reproductive failure and the population decline of invasive light brown apple moths (Epiphyas postvittana), a significant agricultural pest (Brockerhoff et al. 2012). Investigators recently identified at least five volatile compounds emitted by Plasmodium chaubaudi-infected mice (a model of human malarial infection) that attract mosquitoes, and another that repels them (De Moraes et al. 2014). These findings could be used to develop new signal disrupting pesticides that reduce the risk of mosquito-borne diseases.

\section{Biocontrol advancements}

Biological control (hereafter biocontrol) is the management of invasive species or other pests through the introduction of another organism that will limit its population growth and spread, typically through disease, parasitism, or predation. In 2015, ISAC published a white paper on enhancing the effectiveness of biological control programs targeting invasive species by utilizing integrated pest management, a combination of chemical, biological, and physical control (ISAC 2015). Federal agencies are working on a wide-range of other scientific and technical improvements to traditional biocontrol, much of which is coordinated through the Technical Advisory Group for
Biological Control Agents of Weeds (https://www. aphis.usda.gov/aphis/ourfocus/planthealth/importinformation/permits/regulated-organism-and-soilpermits/biological-control-organism-permits/sa_tag, accessed 30 October 2019). More specific examples include the USGS Forest and Rangeland Ecosystem Science Center collaborative efforts to test and assess the impact and efficacy of bacteria (ACK55, "black fingers of death") to control cheatgrass (Bromus tectorum), as well as USFWS support of Stephen F. Austin State University research on the use of giant salvinia (Salvinia molesta) extracts to manage the species, as well as other organisms, with few nontarget impacts.

From ecological and human health perspectives, there is a strong interest in eradicating, or at least containing, invasive mosquitoes and the invasive pathogens vectored by mosquitoes. The US Agency for International Development (USAID), through its Zika Grand Challenge, recently funded research into the use the bacterium Wolbachia pipientis to combat Zika. Wolbachia plagues approximately $60 \%$ of insect species worldwide (Hilgenboecker et al. 2008) but doesn't naturally infect the yellow fever mosquito (Aedes aegypti). Infecting A. aegypti with Wolbachia hinders the mosquito's ability to transmit Zika, dengue, and chikungunya to humans; reduces the fertility of the mosquito hosts; and influences the sex ratio of offspring (Aliota et al. 2016; Molloy et al. 2016). Moreover, A. aegypti pass the bacteria intergenerationally (Walker et al. 2011; Ye et al. 2015). Verily Life Sciences, LLC created a program called Debug, through which it intends to raise and release sterile male mosquitoes infected with Wolbachia to eliminate disease-carrying mosquitoes. The approach is being explored as a tool to manage avian malaria in Hawaii, where the disease has decimated endemic avifauna (LaPointe et al. 2012).

\section{Genetic advancements}

Genome Engineering and Gene Editing A modern synthesis of biology and technology has created the entirely new field of synthetic biology, a subdiscipline of molecular biology that merges biology with engineering, where scientists are able to design (or redesign) species' genomes and fabricate novel biological functions and systems that do not exist in the natural world. For example, clustered regularly 
interspaced short palindromic repeats (CRISPR), CRISPR-associated protein 9 (Cas9) endonuclease, and other molecular tools enable precise genomic editing by allowing scientists to make specific base edits, delete or add a specific gene, and insert a large pieces of DNA at multiple positions within a genome (Cong et al. 2013; Barrangou and Doudna 2016; Rees and Liu 2018). These advances have the potential to create highly efficient tools to eradicate invasive species. ISAC recently reviewed the application of advanced genetic technologies to invasive species prevention and management and made recommendations to NISC for improving policy, research, and advisory frameworks (ISAC 2017).

Mosquitoes are among the first targets of gene editing for invasive species eradication. In Brazil, Oxitec has pioneered a new Friendly ${ }^{\mathrm{TM}} A$. aegypti mosquito control approach by placing a self-limiting gene that causes offspring to die, and a marker gene that allows the organism to be monitored, into the $A$. aegypti mosquito. Males, which do not bite or transmit disease, are sorted and released. When a male mates a wild female it passes the self-limiting gene on to all its offspring, which die before reaching adulthood. Unlike other approaches, Friendly ${ }^{\mathrm{TM}}$ mosquitoes die along with their offspring, and therefore do not persist in the environment or leave any ecological footprint (Winskill et al. 2015). The technique is a variation of an earlier approach in which the DNA of the male mosquitoes is damaged through irradiation and the mass release of these sterile males suppresses population growth (Piaggio et al. 2017).

Five efficacy trials showed greater than $90 \%$ suppression of A. aegypti in the Cayman Islands, Brazil, and Panama. These results compare favorably to conventional mosquito control methods that at best are only able to suppress $A$. aegypti populations by an estimated 30-50\%. In Brazil and the Cayman Islands, the Oxitec approach is now in programmatic use, and currently being deployed in areas that cover over 65,000 people, thus demonstrating scalable capabilities for area-wide control of this disease-carrying mosquito. In 2016, Oxitec received a final finding of no significant impact and final environmental assessment from the US Food and Drug Administration (FDA) for an investigational trial in the Florida Keys. The FDA team, which consisted of experts from the Center for Veterinary Medicine (CVM), the Centers for Disease Control and Prevention (CDC), and the
EPA, concluded that the reared mosquitoes will have no significant impact on human health, animal health, or the environment (Conservation X Labs 2017b). This approach is also being explored as an option for addressing avian malaria in Hawaii (Piaggio et al. 2017). While a promising technology, a recent study of the Oxitec release program in Jacobina, Brazil, detected portions of the transgenic mosquito strain's genome in the target mosquito population, which suggests the critical need for genetic monitoring programs to work in tandem with such releases (Evans et al. 2019).

Gene silencing USGS GLSC and partners are exploring the use of gene silencing as a means of managing Phragmites australis at a land-scape scale (https://www.usgs.gov/centers/glri/science/invasivephragmites-science, accessed 30 October 2019). The genetic approach is seeking a species-specific control option for managers, which could be useful in sensitive areas or areas where conventional control efforts are not practical. RNA-based gene selecting disrupts the transmission of genetic information necessary for protein synthesis and train development. Thus, for example, if genes essential for photosynthesis are silenced, a plant will fail to produce energy for itself.

Ribonucleic acid interference (RNAi). RNAi is a biological process in which RNA molecules inhibit gene expression or translation by neutralizing targeted messenger RNA molecules through an increase or decrease in their activity. In the wild, this approach may protect species against viruses that insert parasitic nucleotide sequences. This approach has been used as a potential cure for cancer (Titze-de-Almeida et al. 2017) and in agriculture (Zotti et al. 2018). It may also be applicable for invasive species as a highly precise (taxa specific), efficient, and stable biopesticide, using prey species as vectors for transmission. Vertebrates may also digest RNA nanoparticles, which may serve as a delivery vehicle (Campbell et al. 2015).

Gene drives A gene drive is a naturally occurring mechanism that promotes the inheritance of a particular gene to increase its prevalence in a population (Burt 2003). In theory, gene drives could be used to push deleterious traits into an invasive population, thereby reducing the population's overall fitness (Esvelt et al. 2014). For example, it may be feasible to use the "sex ratio distortion" drive (Galizi et al. 2014; Hammond et al. 2016), which results in fertile offspring of only one sex, to be used to eradicate 
populations of invasive species by "breeding that population out of existence" (Piaggo et al. 2017). Scientists are also exploring gene drives to ameliorate insect- and animal-borne pathogens (Esvelt and Buchthal 2016; Esvelt et al. 2014; Sinkins and Gould 2006), eradicate invasive rodents in the island context (Campbell et al. 2015), and address a range of other species including cane toads (Rhinella marina), feral cats (Felis catus), and invasive mussels (Moro et al. 2018). The latter work is being conducted through a partnership that includes USDA scientists and is being partially funded by DOD's Defense Advanced Research Projects Agency (DARPA).

Moro et al. (2018), Piaggio et al. (2017), and the National Academies of Sciences, Engineering, and Medicine (2016), among others, have explored issues with gene drive application, including the potential for gene transfer between modified individuals and related taxa, public opposition, and unanticipated ecosystem effects following successful eradication. However, there are several experimental mitigation strategies to reduce the risk of the uncontrolled genetic modification of wild populations (Esvelt et al. 2014), like "reversal" gene drives, or "immunization" gene drives to protect against deleterious ones. Fine-tuning of the genetic burden of the gene drive, or "daisychaining" multiple gene drive elements into distinct portions of the genome, could allow implementers to limit the transfer of modified genes (Esvelt et al. 2014). However, recent mathematical models suggest that gene drives are best suited to applications where the impact is intended to affect all wild populations of the target species, like in malaria prevention (Noble et al. 2018). DARPA's Safe Genes program is supporting advances in synthetic biology, as well as approaches to mitigate the risk of unintentional consequences or intentional misuse of these technologies (https://www.darpa.mil/program/safe-genes, accessed 30 October 2019).

\section{Fostering innovation}

Although invasive species are having a substantial impact on highly valued assets and addressing the problem is fraught with challenges, those of us intent on solving the problem need to move away from a focus on "doom and gloom" and towards a perspective of optimism and innovation. Invasion biology, as a field, could benefit by becoming more solutionsoriented, open to novel ideas, engaging partners from other disciplines, and inviting new perspectives and models for technical application.

Federal agencies have important roles in incentivizing technology development and application. Attracting new solvers and potential paths forward is a critical element for stimulating the innovation pipeline. Prizes and challenges can bring in new solvers from new disciplines and are pay-for-performance mechanisms that do not prejudge the solution or influence the potential solution range. Mass collaboration, co-creation, and open source approaches also serve to encourage collaboration across non-traditional disciplines. This may include crowdsourcing data to increase the leverage of public sector actions. Expanding citizen science initiatives and public-private partnerships provide additional opportunities to call in and engage new solvers and solutions.

Open source mass collaboration

Greater degrees of global connectivity have created a new paradigm of open source science, which is transforming how scientific discoveries are made and technological solutions are created. Open source approaches can help develop and/or source new ideas or products, distribute the burden for collecting and analyzing data, co-design new solutions, and share in the burdens of research, publication, and funding, while simultaneously engaging the public. Such innovation is useful for soliciting expertise and applications from other fields. Open innovation through mass collaboration, especially when combined with prizes and challenges, can transform how problems are solved by sourcing solutions from various disciplines around the world. Researchers found, in general, that the more distant a solver was from the industry, the more novel the solution (Franke et al. 2014). Through the America Creating Opportunities to Meaningfully Promote Excellence in Technology, Education, and Science Act (COMPETES), federal agencies can offer prizes and conduct competitions to encourage innovation, seek solutions to tough problems, and advance an agency's core mission. Since the COMPETES Act was signed, the US government has utilized a number of open innovation tools to incentivize people who might not 
be the usual subject matter experts to assist with data analysis, the creation of decision support systems, solutions to grand challenges, and data visualizations. The federal government can use innovation tools to improve the discovery, speed, and scale of technologies to enhance EDRR capacities.

One example of a successful open mass collaboration is Open Source Drug Discovery (OSDD) (http:// www.osdd.net/, accessed 30 October 2019), which used open mass collaboration to develop new drugs for neglected tropical diseases and made the resulting drug formulations readily available for anyone to license. OSDD collaboratively aggregates the biological, genetic, and chemical information available to scientists to hasten the discovery of drugs among bioinformaticians, wet lab scientists, contract research organizations, clinicians, hospitals and others who are willing to adhere to the affordable healthcare philosophy and agree to the OSDD license.

Ideation, hackathons, and crisis mapping

Ideation events, hackathons, and crisis mapping are collaborative techniques to encourage interdisciplinary collaboration and innovation. Ideation events bring people together, usually from a range of disciplines, to innovate new solutions to societal problems. Conservation X Labs and the NISC Secretariat recently collaborated in multiple ideation events to harness new thinking for invasive species problem resolution. Teams at the 2017 Make for the Planet event hosted at the Smithsonian Institution's Earth Optimism Summit (https://www.makefortheplanet. com/home, accessed 30October 2019) generated ideas to detect invasive species in logistically-challenging landscapes, for example. At the $2018 \mathrm{Big}$ Think for Water Conservation, participants proposed solutions to addressing aquatic invasive vegetation (https://conservationxlabs.com/water-challenge, accessed 30 October 2019).

Hackathons or codefests are events where computer programmers, design experts, and subject-matter experts collaborate within a specific amount of time to sort through and "hack" data to produce more solutions. In the invasive species context, hackathons can help engineer solutions to problems where, for example, there are large data sets or the need to create decision support systems. In 2017, NASA hosted Space Apps hackathon that included a tool for tracking invasive species in your neighborhood over time (https://2017.spaceappschallenge.org/challenges/ourecological-neighborhood/trace-invaders/details, accessed 30 October 2019).

Crisis mappers have pioneered new approaches to harness mobile and web-based applications, participatory maps and crowd sourced event data, aerial and satellite imagery, geospatial platforms, advanced visualization, live simulation, and computational and statistical models (Avvenuti et al. 2016). Crisis mappers use these approaches to create effective early warning systems for rapid response to complex humanitarian emergencies. For example, crisis mapping in response to the $2015 \mathrm{Nepal}$ earthquake helped responders locate survivors and roads after people all over the world digitized street maps (Parker 2015). Extreme weather events can spread invasive species into new water bodies through flooding and/or as hitchhikers on floating debris. USGS scientists have created online "storm tracker" maps to project the potential spread of non-native aquatic plant and animal species as a result of hurricane activity (Neilson et al. 2018).

Prizes and challenges

Prizes and challenges are competitive performancebased mechanisms that can draw upon novel disciplines, harness innovations from adjacent sectors, and attract innovators with the intent of inspiring new solutions to substantial problems. Prizes and challenges can "crowdsource" new solutions with the recognition that breakthroughs may not come from expected disciplines or institutions. A prize focuses on a single breakthrough, while a challenge helps create new communities of solutions and practice. Prizes and challenges focus on defining the issue and its constraints, rather than directing participants to a specific solution. Accordingly, such open innovation mechanisms can be much more efficient than traditional grants as they only reward the achievement of the goal, rather than a promise (grant) or commitment (contract) to achieve the goal. A prize can be a useful tool to inspire problem solvers to invest their expertise in developing a specific breakthrough. In contrast to a prize, a challenge provides grants or equity investments to multiple winners that meet the terms of the challenge. 
The US Agency for International Development (USAID) started a Grand Challenges initiative through its Global Development Lab (https://www.usaid.gov/ GlobalDevLab, accessed 30 October 2019) in an effort to catalyze solutions to sustainable development problems, which could include a wide range of invasive species impacts (e.g., food and water security, human health, human conflict). They have successfully used open innovation for responses to Ebola and Zika outbreaks.

The DOI Bureau of Reclamation has used prizes to inspire solutions to invasive quagga and zebra mussels (https://www.usbr.gov/mussels, accessed 30 October 2019), while the DOI Office of Native Hawaiian Relations sponsored a prize for technologies to detect and cure Rapid Ohi'a Death (https://conservationx. com/challenge/invasives/ohia, accessed 30 October 2019). Federal government challenges are posted on the Challenge.gov website (https://challenge.gov, accessed 30 October 2019).

The state of Michigan recently concluded the Great Lakes Invasive Carp Challenge (https://www. michigan.gov/dnr/0,4570,7-350-84430_84439—,00. html, accessed 30 October 2019) to source solutions that will stop invasive carp from reaching the Great Lakes. One of the winning ideas, "Cavitation Barrier to Deter Asian Carp," involves specially designed propellers that generate a wall of cavitation bubbles, which implode and cause high-speed jets of water to repel and prevent fish passage beyond the bubble barrier.

Recently, Conservation X Labs and the NISC Secretariat collaborated in the development of the Digital Makerspace (https://conservationx.com, accessed 30 October 2019) an online platform for community-based ideation, challenges, and prizes. The platform was launched in 2018 during National Invasive Species Awareness Week with a focus on three invasive species challenges: detection technologies for the chytrid fungi impacting amphibians worldwide (https://conservationx.com/challenge/ invasives/chytrid, accessed 30 October 2019), detection technologies and a cure for the chytrid fungus attacking ohia trees in Hawaii (see above), and the detection of rodents on remote islands post eradication efforts (https://conservationx.com/challenge/ invasives/zero, accessed 30 October 2019). The platform remains open to additional invasive species challenges and prizes.

\section{Making innovation applicable}

Taking technology to market and scale

Establishing a strategy for marketing and scaling up the application of a technology is just as important as the innovation itself. Scale and market sustainability as part of the core innovation design process is critical to achieving the greatest impact. Federal agencies are also contributing critical leadership roles in this regard.

The National Science Foundation's (NSF) Innovation Corps (I-Corps) program (https://www.nsf.gov/ news/special_reports/i-corps/, accessed 30 October 2019) helps researchers translate discoveries into technologies and products with near-term benefits for the economy and society, and in the long term, into commercial enterprises. The program teaches NSF grantees to identify valuable product opportunities that can emerge from academic research and offers entrepreneurship training to participants.

The I-Corps program applies the scientific method to entrepreneurship by encouraging researchers to test their hypotheses about demand. In this process, it is critical for researchers, such as the creators of artificial coral reefs, to get out of their technical area of practice to determine whether there is broader market demand for a product, and if not, how a "product" should be redesigned in the face of that evidence. Although we are not aware of specific examples in the invasive species field to date, the potential certainly exists for the support of invasive species innovations emerging through the NSF granting and I-Corps programs.

Small businesses can be nimble catalysts for change and can commercialize solutions, and entrepreneurs need financing to capitalize on high-risk/high-reward approaches. The government has a role to play to incentivize innovation, which can help draw experts from other disciplines. Different types of supporting resources (e.g., mentorship networks) and forms of capital (e.g., intellectual, social, financial) can be offered to entrepreneurs, but strong motivators, such as love, pride, and fear are also important drivers.

The US Small Business Innovation Research (SBIR) program (https://www.sbir.gov, accessed 30 October 2019) is a highly competitive program that encourages domestic, small businesses to engage in research and development that have the potential for commercialization. Through a competitive awards- 
based program, SBIR enables small businesses to explore their technological potential and provides incentives to profit from commercialization. By including qualified small businesses in the nation's research and development arena, high-tech innovation is stimulated, and the US reinforces an entrepreneurial spirit as it meets specific research and development needs. Such programs are useful for taking research out of the lab and turning it into tangible products and services that are the basis for scalable enterprises.

A key lesson learned from experiences with the SBIR program is the importance of connecting a problem to an economic opportunity (e.g., an invasive species grand challenge) in order to create a demand for new innovation. In this regard, government agencies need to consider how they use these tools and levers to build private sector opportunities.

\section{Advancing regulatory frameworks}

Federal rulemaking can have a profound influence on technology development and application; the nature of that influence can either facilitate or limit effective outcomes. Although many view federal regulations as suppressing commercialization or undermining innovation, the federal government's goal is to increase predictability for technology development and ensure public safety. Contrary to popular belief, the US government does not regulate technologies or processes (i.e., gene editing), rather it regulates products. New regulatory challenges are arising with the advent of new technologies (esp. biotechnologies) that do not fall clearly into existing areas of an agency's responsibility, or that cut across multiple agencies (ISAC 2017). In the case of advanced biotechnology applications for invasive species, the Coordinated Framework for the Products of Biotechnology provides an iterative mechanism for the relevant regulatory agencies to coordinate on how to address present and future technologies (Office of Science and Technology Policy 2016a, b; National Academies of Sciences, Engineering and Medicine 2017). Burgos-Rodriquez and Burgiel (2019, this issue) provide a broad overview of legal and policy matters influencing EDRR in the US context.
Summary of needs and conclusion

Through the Innovation Summit and survey of federal capacities for applying technologies to EDRR federal agencies have identified a wide range of opportunities to advance technological innovation for and application to the invasive species issue. The Innovation Summit report includes a summary of actions needed to advance technologies for the prevention, eradication, and control of invasive species more broadly (Conservation X Labs 2017a). Below we provide an overview of the primary needs identified by the federal agencies to further their ability to increase technology effectiveness and cost-efficiency in the EDRR context. See Reaser (2019, this issue) for these recommendations in the context of a comprehensive blueprint for a national EDRR program.

1. Increase and modernize research facilities. Federal agencies need adequate facilities to conduct the research necessary to develop and test new technological solutions. This includes facilities for improving understanding of animal biology and behavior (e.g., what kind of bait they will eat, how they behave around certain traps), as well as sophisticated biosafety laboratories for handling risky organisms (e.g., pathogens) or toxins. Facilities need to enable operations consistent with changing regulations, new approaches, and study replication. Region-based facilities would enable prioritization of work on specific species of particular concern at that locality and thus foster greater opportunities for partnerships with other institutions with similar concerns.

2. Expand staff capacities. Federal agencies need a workforce of innovators that includes staff with particular expertise in emerging fields of application to the invasive species issue, especially genetics, engineering, and bioinformatics. Detailing staff between agencies (e.g., DOD intelligence or military technology staff to CBP or USGS) could substantially increase opportunities for identifying dual-use technologies that could meet federal needs with little additional investment. Research partnerships with non-federal institutions, particularly with the private sector or academia, could also increase the workforce focused on finding solutions to specific invasive species problems. 
3. Improve information infrastructure. Federal agencies routinely cite limits in the availability of data and decision support tools as barriers to effectively addressing invasive species. Reaser et al. (2019b, this issue) and Wallace et al. (2019, this issue) broadly address information needs in the EDRR context as part of this Special Issue. In the context of technology advancement, agencies emphasized the need for:

a. Genetic libraries (DNA fingerprinting) to enable identification tool development and cell lines of current and potential invaders to allow in vitro screening of potential control agents. Ideally, agencies would collaborate within the United States and with international partners in the development and operation of a functional genomics and metabolomics database of current and potential invaders;

b. Biological data that will enable agencies to target technologies for use on specific invasive species in a wide-range of contexts with minimal impact on non-target organisms;

c. Data on non-native species being imported into the United States and/or otherwise moving through US trade to enable horizon scanning and pathway analyses; and

d. Spatial analysis data that are web-accessible, can be coupled with other datasets (e.g., species occurrence, pathways, biology), and are accessible by non-federal collaborators.

4. Advance priority technologies. Federal agencies identified the following technologies as needing greater support from financial, institutional, and/ or regulatory perspectives:

a. Surveillance technologies (from sonar to satellites) that will greatly facilitate nonnative species detection at points of entry and in logistically challenging situations (e.g., underwater, in remote locations, at night);

b. Identification tools, particularly devices that can be field-employed and allow for immediate recording of locality, data logging, and reporting to authoritative identifiers;

c. Response tools that will be effective, socially acceptable, and cost-efficient, with an emphasis on increasing research and regulation to facilitate the use of genetic-based technologies and other alternatives to traditional pesticides that can be used in logistically challenging contexts. Partnerships among agencies and with non-federal institutions may be necessary to address registration and other regulatory requirements in a timely manner; and

d. Drone technology enabling broad detection and response application on federal lands and lands managed by federal partners.

5. Use prizes and challenges to complement more traditional grants and agreements. Although some federal agencies are already employing prizes and challenges to encourage solutions to invasive species challenges that are undermining their mission capacity and endangering the assets they manage, there are substantial opportunities for expanding these programs more broadly across the federal government and providing resources to scale solutions.

6. Foster a thriving culture of innovation and community of practice. The Innovation Summit and Digital Makerspace, both responses to 2016-2018 NISC Management Plan (NISC 2016) priorities, are platforms for fostering a community of solvers within and among federal agencies, as well as with federal partners. The expansion of these initiatives is needed, as well as a forum for ongoing interagency dialogue between federal agency staff faced with invasive species challenges and the government research and development experts who have problem-solving expertise (esp. in the fields of intelligence, engineering, and genetics).

Investments in technological innovation are rapidly advancing our ability to prevent, eradicate, and control invasive species. There is renewed hope that we can overcome the invasive species challenges that have thus far seemed insurmountable. The application of emerging and dual-use technologies can represent a long-term cost-savings compared to the existing, often inefficient and ineffective, practices currently in the invasive species toolbox. Prioritizing technology innovation can have substantial payoffs-potentially saving millions of dollars in costs posed by a single species. Federal agencies and their partners have a clear role in identifying challenges and opportunities, 
inspiring innovation, expand investment, and reducing barriers to the development and application of possible solutions.

Acknowledgements This paper advances action 5.1.6 of the 2016-2018 NISC Management Plan. The authors are grateful to everyone who contributed to the federal agency surveys and supplemental inquires. The authors thank Karl Campbell, Keith Gaddis, Steve Gittings, Jeffrey Morisette, Stanley Burgiel, Jason Kirkey, Cassie Hoffman, Kelly Pennington, Lucas Joppa, Chuck Bargeron, Will Reagan, Laura Meyerson, and Dan Simberloff for reviews that improved the manuscript. Kevin Esvelt and B. Zamft contributed useful discussions regarding gene drives. Financial support for this project was provided through Service First funding to the NISC Secretariat. Any use of or reference to trade, firm, or product names is for descriptive purposes only and does not imply endorsement by the United States Government. The views expressed in this publication are solely those of the authors and do not necessarily reflect the views of the United States Government. The majority of Jamie K. Reaser's contributions occurred while Executive Director of the National Invasive Species Council.

Open Access This article is distributed under the terms of the Creative Commons Attribution 4.0 International License (http:// creativecommons.org/licenses/by/4.0/), which permits unrestricted use, distribution, and reproduction in any medium, provided you give appropriate credit to the original author(s) and the source, provide a link to the Creative Commons license, and indicate if changes were made.

\section{References}

Afsharinejad A, Davy A, Jennings B, Brennan C (2016) Performance analysis of plant monitoring nanosensor networks at THz frequencies. IEEE Internet Things J 3:59-69. https://doi.org/10.1109/JIOT.2015.2463685

Aliota MT, Walker EC, Uribe Yepes A, Dario Velez I, Christensen BM, Osorio JE (2016) The wMel strain of Wolbachia reduces transmission of chikungunya virus in Aedes aegypti. PLoS Negl Trop Dis 10:1-7. https://doi.org/10. 1371/journal.pntd.0004677

Armstrong KF, Ball SL (2005) DNA barcodes for biosecurity: invasive species identification. Philos Trans R Soc Lond B Biol Sci 360:1813-1823. https://doi.org/10.1098/rstb. 2005.1713

Asner GP, Knapp DE, Kennedy-Bowdoin T, Jones MO, Martin RE, Boardman JH, Flint R (2008) Invasive species detection in Hawaiian rainforests using airborne imaging spectroscopy and LiDAR. Remote Sens Environ 112:1942-1955

Avery ML, Humphrey JS, Keacher KL, Bruce WE (2014) Detection and removal of invasive Burmese pythons: methods development update. In: Timm RM, O'Brien JM (eds) Proceedings of the 26th Vertebr Pest Conf University of California, Davis, pp 145-148
Avvenuti M, Cresci S, Del Vigna F, Tesconi M (2016) Impromptu crisis mapping to prioritize emergency response. Comput (Long Beach Calif) May:28-37

Baietto M, Aquaro S, Wilson AD, Pozzi L, Bassi D (2015) The use of gas-sensor arrays in the detection of bole and root decays in living trees: development of a new non-invasive method of sampling and analysis. Sens Transducers 193:154-160

Banerji M, Lahav O, Lintott CJ, Abdalla FB, Schawinski K, Bamford SP, Andreescu D, Murray P, Raddick MJ, Slosar A, Szalay A, Thomas D, Vandenberg J (2010) Galaxy zoo: reproducing galaxy morphologies via machine learning. Mon Not R Astron Soc 406:342-353. https://doi.org/10. 1111/j.1365-2966.2010.16713.x

Barbosa J, Sebastián-Gonzáles E, Asner G, Knapp D, Anderson C, Martin R, Dirzo R (2016) Hemiparasite-host plant interactions in a fragmented landscape assessed via imaging spectroscopy and LiDAR. Ecol Appl 26:55-66. https:// doi.org/10.1890/14.2429.1/suppinfo

Baron J, Hill DJ, Elmiligi H (2018) Combining image processing and machine learning to identify invasive plants in high-resolution images. Int J Remote Sens 1-20:5099-5118. https://doi.org/10.1080/01431161.2017. 1420940

Barrangou R, Doudna JA (2016) Applications of CRISPR technologies in research and beyond. Nat Biotechnol 34:933-941. https://doi.org/10.1038/nbt.3659

Beaumont CN, Goodman AA, Kendrew S, Williams JP, Simpson R (2014) The Milky Way Project: leveraging citizen science and machine learning to detect interstellar bubbles. Astrophys J Suppl Ser 214:3. https://doi.org/10.1088/00670049/214/1/3

Behmann J, Mahlein AK, Rumpf T, Römer C, Plümer L (2015) A review of advanced machine learning methods for the detection of biotic stress in precision crop protection. Precis Agric 16(3):239-260

Benson DA, Cavanaugh M, Clark K, Karsch-Mizrachi I, Lipman DJ, Ostell J, Sayers EW (2013) GenBank. Nucleaic Acids Res 41:36-42. https://doi.org/10.1093/nar/gks1195

Bilodeau P, Roe AD, Bilodeau G, Blackburn GS, Cui M et al (2018) Biosurveillance of forest insects: part II-adoption of genomic tools by end user communities and barriers to integration. J Pest Sci 92:1-12

Bradley BA (2014) Remote detection of invasive plants: a review of spectral, textural and phenological approaches. Biol Invasions 16:1411-1425. https://doi.org/10.1007/ s10530-013-0578-9

Bradshaw CJA, Leroy B, Bellard C, Roiz D, Albert C, Fournier A, Barbet-Massin M, Salles JM, Simard F, Courchamp F (2016) Massive yet grossly underestimated global costs of invasive insects. Nat Commun. https://doi.org/10.1038/ ncomms 12986

Brockerhoff EG, Suckling DM, Kimberley M, Richardson B, Coker G, Gous S, Kerr JL, Cowan DM, Lance DR, Strand $\mathrm{T}$, Zhang A (2012) Aerial application of pheromones for mating disruption of an invasive moth as a potential eradication tool. PLoS ONE. https://doi.org/10.1371/journal. pone. 0043767

Burgos-Rodríguez J, Burgiel SW (2019) Federal legal authorities for the early detection of and rapid response to invasive 
species. Biol Invasions. https://doi.org/10.1007/s10530019-02148-w

Burt A (2003) Site-specific selfish genes as tools for the control and genetic engineering of natural populations. Proc R Soc Lond 270(1518):921-928

Burton AC, Neilson E, Moreira D, Ladle A, Steenweg R, Fisher JT, Bayne E, Boutin S (2015) Wildlife camera trapping: a review and recommendations for linking surveys to ecological processes. J Appl Ecol 52:675-685. https://doi.org/ 10.1111/1365-2664.12432

Campbell KJ, Beek J, Eason CT, Glen AS, Godwin J, Gould F, Holmes ND, Howald GR, Madden FM, Ponder JB, Threadgill DW, Wegmann A, Baxter GS (2015) The next generation of rodent eradications: innovative technologies and tools to improve species specificity and increase their feasibility on islands. Biol Conserv 185:47-58. https://doi. org/10.1016/j.biocon.2014.10.016

Cantrell B, Martin L, Ellis EC (2017) Designing autonomy: opportunities for new wildness in the anthropocene. Trends Ecol Evol 32:287-331. https://doi.org/10.1016/j.tree.2016. 12.004

Chen H, Yada R (2011) Nanotechnologies in agriculture: new tools for sustainable development. Trends Food Sci Technol 22:585-594. https://doi.org/10.1016/j.tifs.2011. 09.004

Chikkadi K, Roman C, Durrer L, Süss T, Pohle R (2012) Scalable fabrication of individual SWNT chem-FETs for gas Sensing. Procedia Eng 47:1374-1377. https://doi.org/10. 1016/j.proeng.2012.09.412

Cong L, Ran FA, Cox D, Lin S, Barretto R, Habib N, Hsu PD, Wu X, Jiang W, Marraffini LA, Zhang F (2013) Multiplex genome engineering using CRISPR/Cas systems. Science 80(339):819-823. https://doi.org/10.1126/science. 1231143

Connelly NA, O'Neill CR, Knuth BA, Brown TL (2007) Economic impacts of zebra mussels on drinking water treatment and electric power generation facilities. Environ Manage 40:105-112. https://doi.org/10.1007/s00267-0060296-5

Conservation X Labs (2017a) The innovation summit report. National Invasive Species Council Secretariat, Washington, DC

Conservation X Labs (2017b) The Innovation Summit report: annexes. National Invasive Species Council Secretariat, Washington, DC

Dash J, Ogutu BO (2016) Recent advances in space-borne optical remote sensing systems for monitoring global terrestrial ecosystems. Prog Phys Geogr 40:322-351. https:// doi.org/10.1177/0309133316639403

Daume S (2016) Mining Twitter to monitor invasive alien species: an analytical framework and sample information topologies. Ecol Inform 31:70-82. https://doi.org/10.1016/ j.ecoinf.2015.11.014

Dawson DK, Efford MG (2009) Bird population density estimated from acoustic signals. J Appl Ecol 46(6):1201-1209

De Moraes CM, Stanczyk NM, Betz HS, Pulido H, Sim DG, Read AF, Mescher MC (2014) Malaria-induced changes in host odors enhance mosquito attraction. Proc Natl Acad Sci USA 111:11079-11084. https://doi.org/10.1073/pnas. 1405617111
Delord K, Roudaut G, Guinet C, Barbraud C, Bertrand S, Weimerskirch H (2015) Kite aerial photography: a lowcost method for monitoring seabird colonies. J F Ornithol 86:173-179. https://doi.org/10.1111/jofo.12100

Drake KK, Bowen L, Nussear KE, Esque TC, Berger AJ, Custer NA, Waters SC, Johnson JD, Miles A, Lewison RL (2016) Negative impacts of invasive plants on conservation of sensitive desert wildlife. Ecosphere 7:1-20. https://doi.org/ 10.1002/ecs 2.1531

Dunker K, Sepulveda A, Massengill R, Olsen JB, Russ OL, Wenburg JK, Antonovich A (2016) Potential of environmental DNA to evaluate northern pike (Esox lucius) eradication efforts: an experimental test and case study. PLoS ONE 11:e0162277. https://doi.org/10.1371/journal. pone. 0162277

Ericsson (2016) Ericsson mobility report. Stockholm

Esvelt KM, Buchthal S (2016) Heritably immunizing whitefooted mice against tick-borne disease: project narrative. https://assets.pubpub.org/2b8fjlhj/31508173184036.pdf. Accessed 4 Oct 2018

Esvelt KM, Smidler AL, Catteruccia F, Church GM (2014) Concerning RNA-guided gene drives for the alteration of wild populations. Elife 3:e03401. https://doi.org/10.7554/ eLife.03401

Evans BR, Kotsakiozi P, Costa-da-Silva AL, Ioshino RS, Garziera L, Pedrosa MC, Aldo Malavasi, Virginio JF, Capurro ML, Powell JR (2019) Transgenic Aedes aegypti Mosquitoes Transfer Genes into a Natural Population. Sci Rep 9:13047. https://doi.org/10.1038/s41598-019-49660-6

Executive Office of the President (2016) Executive Order 13751, 81 FR 88609-88614, 5 December 2016

Ferracane J (2016) New 5-mile cat-proof fence protects endangered Hawaiian petrels on Mauna Loa, National Park Service https://www.nps.gov/havo/learn/news/20161024_ pr_cat_fence.htm. Accessed 9 Oct 2018

Figueroa-Alfaro RW, Tang Z (2017) Evaluating the aesthetic value of cultural ecosystem services by mapping geo-tagged photographs from social media data on Panoramio and Flickr. J Environ Plan Manag 60:266-281. https://doi.org/ 10.1080/09640568.2016.1151772

Flynn T, Salloum H, Hull-Sanders H, et al (2016) Acoustic methods of invasive species detection in agriculture shipments. In: IEEE Symposium on Technologies for Homeland Security (HST) 2016. https://doi.org/10.1109/ths. 2016.7568897

Foote AD, Thomsen PF, Sveegaard S, Wahlberg M, Kielgast J, Kyhn LA, Salling AB, Galatius A, Orlando L, Gilbert MTP (2012) Investigating the potential use of environmental DNA (eDNA) for genetic monitoring of marine mammals. PLoS ONE. https://doi.org/10.1371/journal.pone.0041781

Franke N, Poetz MK, Schreier M (2014) Integrating problem solvers from analogous markets in new product ideation integrating problem solvers from analogous markets in new product ideation. Manage Sci 60:1063-1081

Fronte K and Garth J (2015) Enhanced sampling of young Asian Carp in the Illinois River, US Fish and Wildlife Service Fishlines https://www.fws.gov/midwest/fisheries/fishlines2015-12-16/feature5.html. Accessed 9 Oct 2018

Fukuhara R, Yamaguchi T, Ukuta H, Roy S, Tanaka J, Ogura G (2010) Development and introduction of detection dogs in surveying for scats of small Indian mongoose as invasive 
alien species. J Vet Behav Clin Appl Res 5:101-111. https://doi.org/10.1016/j.jveb.2009.08.010

Galizi R, Doyle LA, Menichelli M, Bernardini F, Deredec A, Burt A, Stoddard BL, Windbichler N, Crisanti A (2014) A synthetic sex ratio distortion system for the control of the human malaria mosquito. Nat Commun 5:3977. https://doi. org/10.1038/ncomms4977

Gallo T, Waitt D (2011) Science model to detect and report invasive species. Bioscience 61:459-465

Garcia S, Leitch IJ, Anadon-Rosell A, Canela MA, Galvez F et al (2014) Recent updates and developments to plant genome size databases. Nucleic Acides Res 42:1159-1166. https://doi.org/10.1093/nar/gkt1195

Glen AS, Anderson D, Veltman CJ, Garvey PM, Nichols M (2016) Wildlife detector dogs and camera traps: a comparison of techniques for detecting feral cats. New Zeal J Zool 43:127-137. https://doi.org/10.1080/03014223.2015. 1103761

Gomes IV (2017) Python hunters use high-tech drones to find invasive snakes in the everglades. In: Miami New Times. http://www.miaminewtimes.com/news/python-huntersendorse-thermal-drones-in-the-everglades-9848542. Accessed 2 Jul 2018

Goodwin KM, Engel RE, Weaver DK (2010) Trained dogs outperform human surveyors in the detection of rare spotted knapweed (Centaurea stoebe). Invasive Plant Sci Manag 3:113-121. https://doi.org/10.1614/IPSM-D-0900025.1

Guisan A, Thuiller W (2005) Predicting species distribution: offering more than simple habitat models. Ecol Lett 8:993-1009. https://doi.org/10.1111/j.1461-0248.2005. 00792.x

Guo S, Qiang M, Luan X, Xu P, He G, Yin X, Xi L, Jin X, Shao J, Chen X, Fang D, Li B (2015) The application of the Internet of Things to animal ecology. Integr Zool 10:572-578. https://doi.org/10.1111/1749-4877.12162

Hammond A, Galizi R, Kyrou K, Simoni A, Siniscalchi C, Katsanos D, Gribble M, Baker D, Marois E, Russell S, Burt A, Windbichler N, Crisanti A, Nolan T (2016) A CRISPRCas9 gene drive system targeting female reproduction in the malaria mosquito vector Anopheles gambiae. Nat Biotechnol 34:78-83. https://doi.org/10.1038/nbt.3439

Handford CE, Dean M, Henchion M, Spence M, Elliott T (2014) Implications of nanotechnology for the agri-food industry: opportunities, benefits and risks. Trends Food Sci Technol 40:226-241. https://doi.org/10.1016/j.tifs.2014.09.007

Hart JK, Martinez K (2015) Toward an environmental Internet of Things. Earth Sp Sci 2:194-200. https://doi.org/10. 1002/2014EA000044

Harwin S, Lucieer A (2012) Assessing the accuracy of georeferenced point clouds produced via multi-view stereopsis from unmanned aerial vehicle (UAV) imagery. Remote Sens 4:1573-1599. https://doi.org/10.3390/rs4061573

Hilgenboecker K, Hammerstein P, Schlattmann P, Telschow A, Werren JH (2008) How many species are infected with Wolbachia? A statistical analysis of current data. FEMS Microbiol Lett 281:215-220. https://doi.org/10.1111/j. 1574-6968.2008.01110.x
Hinlo R, Litermans M, Gleeson D, Broadhurst B, Furlan E (2018) Performance of eDNA assays to detect and qualify an elusive benthic fish in upland Streams. Biol Invasion. https://doi.org/10.1007/s10530-018-1760-x

Homan HJ, Linz G, Peer BD (2001) Dogs increase recovery of passerine carcasses in dense vegetation. Wildl Soc Bull 29:292-296

Howald G, Donlan CJ, Faulkner K, Ortega S, Gellerman H, Croll D, Tershy B (2010) Eradication of black rats Rattus rattus from Anacapa Island. Oryx 44:30-40. https://doi. org/10.1017/S003060530999024X

Invasive Species Advisory Committee (ISAC) (2014) Invasive species and e-commerce. National Invasive Species Council Secretariat, Washington, DC

Invasive Species Advisory Committee (ISAC) (2015) Enhancing the effectiveness of biological control programs of invasive species by utilizing an integrated pest management approach. National Invasive Species Council Secretariat, Washington, DC

Invasive Species Advisory Committee (ISAC) (2016) Invasive species impacts on infrastructure. National Invasive Species Council Secretariat, Washington, DC

Invasive Species Advisory Committee (ISAC) (2017) Advanced biotechnology tools for invasive species management. National Invasive Species Council Secretariat, Washington, DC

Jain M, Fiddes I, Miga KH et al (2015) Improved data analysis for the MinION nanopore sequencer. Nat Methods 12:351-356. https://doi.org/10.1161/CIRCRESAHA.116. 303790

Jansen RMC, Wildt J, Kappers IF, Bouwmeester HJ, Hofstee JW, van Henten EJ (2011) Detection of diseased plants by analysis of volatile organic compound emission. Annu Rev Phytopathol 49:157-174. https://doi.org/10.1146/annurevphyto-072910-095227

Jerde CL, Mahon AR, Chadderton WL, Lodge DM (2011) "Sight-unseen" detection of rare aquatic species using environmental DNA. Conserv Lett 4:150-157

John J (2016) Experts hack away at portable DNA barcode scanner to fight timber and wildlife trafficking. Mongabay Wildtech. https://wildtech.mongabay.com/2016/09/ experts-hack. Accessed 28 Aug 2018

Kamenova S, Bartley TJ, Bohan D, Boutain JR, Colautti RI, Domaizon I, Fontaine C, Lemainque A, Le Viol I, Mollot G, Perga ME, Ravigné V, Massol F (2017) Invasions toolkit: current methods for tracking the spread and impact of invasive species. Adv Ecol Invasions 56:1-97. https:// doi.org/10.1016/bs.aecr.2016.10.009

Kendal D, Ford RM (2017) Social license in conservation. Conserv Biol 32:493-495. https://doi.org/10.1111/cobi. 12994

Kendal D, Ford RM et al (2018) Need for empirical evidence to support use of social license in conservation: reply to Garnett. Conserv Biol 32:737-739. https://doi.org/10. 1111/cobi.13114

Kendrot SR (2011) Restoration through eradication: protecting Chesapeake Bay marshlands from invasive nutria ( $M y$ ocastor coypus). In: Island invasives eradication and 
management proceedings of the international conference on eradication of island invasives, pp 313-319

Kessel ST, Cooke SJ, Heupel MR, Hussey NE, Simpfendorfer CA, Vagle S, Fisk AT (2014) A review of detection range testing in aquatic passive acoustic telemetry studies. Rev Fish Biol Fish 24(1):199-218

Klein DJ, Mckown MW, Tershy BR (2015) Deep learning for large scale biodiversity monitoring. In: Bloom Data Good Exch Conf http://bio.research.ucsc.edu/people/croll/pdf/ Klein_2015.pdf. Accessed 2 Jul 2018

Lambe U, Minakshi P, Brar B, Guray M, Ikbal, Ranjan K, Bansal N, Khurana SK, Manimegalai J (2016) Nanodiagnostics: a new frontier for veterinary and medical sciences. J Exp Biol Agric Sci 4:307-320. https://doi.org/10.18006/ 2016.4(3S).307.320

Lane ND, Miluzzo E, Lu H, Peebles D, Choudhury T, Campbell AT (2010) A survey of mobile phone sensing. IEEE Commun Mag 48:140-150. https://doi.org/10.1109/ MCOM.2010.5560598

LaPointe DA, Atkinson CT, Samuel MD (2012) Ecology and conservation biology of avian malaria. Ann New York Acad Sci 1249(1):211-226

Lardner B, Siers SR, Savidge JA, Yackel Adams AA, Reed R (2017) Predicting BTS demographic responses to aerial toxicant baiting scenarios using Program SLITHER: a case study involving the Habitat Management Unit. Brown Treesnake Technical Working Group, Guam, November 22-23, 2017

Lee D, Cullum JP, Anderson JL, Daugherty JL, Beckett LM, Leskey TC (2014) Characterization of overwintering sites of the invasive brown marmorated stink bug in natural landscapes using human surveyors and detector canines. PLoS ONE 9(4):e91575. https://doi.org/10.1371/journal. pone. 0091575

Lieber-Kotz O (2017) NOAA and partners release new trap designs to corral invasive lionfish in deep water, NOAA Sanctuaries https://sanctuaries.noaa.gov/news/feb17/ sanctuary-scientist-fightsinvasive-lionfish.html. Accessed 9 Oct 2018

Lin H-M, Chi W, Lin C, Tseng Y, Chen W, Kung Y, Lien Y, Chen Y (2011) Fire ant-detecting canines: a complementary method in detecting red imported fire ants. J Econ Entomol 104:225-231. https://doi.org/10.1603/EC10298

Linkie M, Guillera-Arroita G, Smith J et al (2013) Cryptic mammals caught on camera: assessing the utility of range wide camera trap data for conserving the endangered Asian tapir. Biol Conserv 162:107-115. https://doi.org/10.1016/j. biocon.2013.03.028

Lyal CHC, Miller SE (2019) Capacity of United States federal government and its partners to rapidly and accurately report the identity (taxonomy) of non-native organisms intercepted in early detection programs. Biol Invasions. https://doi.org/10.1007/s10530-019-02147-x

Mac Aodha O, Gibb R, Barlow KE, Browning E, Firman M et al (2018) Bat detective-deep learning tools for bat acoustic signal detection. PLoS Comput Biol 14(3):e1005995

Macías Macías M, Agudo JE, García Manso A, García Orellana CJ, González Velasco HM, Gallardo Caballero R (2013) A compact and low cost electronic nose for aroma detection. Sensors (Basel) 13:5528-5541. https://doi.org/10.3390/ s130505528
Mack RN, Simberloff D, Lonsdale WM, Evans H, Clout M, Bazzaz FA (2000) Biotic invasions: causes, epidemiology, global consequences and control. Ecol Appl 10:689-710

Malik P, Katyal V, Malik V, Asatkar A, Inwati G, Mukherjee T (2013) Nanobiosensors: concepts and variations. ISRN Nanomater 2013:1-9. https://doi.org/10.1155/2013/ 327435

Martinez B, Dehgan A, Zamft B, Baisch D, McCormick C, et al (2018) Advancing federal capacities for the early detection of and rapid response to invasive species through technology innovation. National Invasive Species Council Secretariat. https://www.doi.gov/sites/doi.gov/files/ uploads/federal_capacities_for_edrr_through_ technology_innovation_contractorsreport_10.22.18.pdf. Accessed 22 Oct 2018

McNeal GS (2016) Drones and the future of aerial surveillance. Geo Wash L Rev 84:354-416

Meyers NM, Reaser JK, Hoff MH (2019) Instituting a national early detection and rapid response program: needs for building federal risk screening capacity. Biol Invasions. https://doi.org/10.1007/s10530-019-02144-0

Meyerson LA, Reaser JK (2003) Bioinvasions, bioterrorism, and biosecurity. Front Ecol Env 1:307-314

Molloy JC, Sommer U, Viant MR, Sinkins SP (2016) Wolbachia modulates lipid metabolism in Aedes albopictus mosquito cells. Appl Environ Microbiol 82:AEM.00275-16. https:// doi.org/10.1128/aem.00275-16

Morisette JT, Reaser JK, Cook GL, Irvine KM, Roy HE (2019) Right place. Right time. Right tool: guidance for using target analysis to increase the likelihood of invasive species detection. Biol Invasions. https://doi.org/10.1007/s10530019-02145-z

Moro D, Byrne M, Kennedy M, Campbell S, Tizard M (2018) Identifying knowledge gaps for gene drive research to control invasive animal species: the next CRISPR step. Global Ecol Conserv 13:e00363

National Academies of Sciences, Engineering, and Medicine (2016) Gene drives on the horizon: advancing science, navigating uncertainty, and aligning research with public values. Washington, DC

National Academies of Sciences, Engineering, and Medicine (2017) Preparing for future products of biotechnology. The National Academies Press, Washington, DC. Doi: https:// doi.org/10.17226/24605

National Invasive Species Council (NISC) (2016) 2016-2018 NISC Management Plan. Washington, DC

Neilson M, Fuller P, Dewar H (2018) USGS tracks how hurricane floodwaters spread non-native freshwater plants and animals. US Geological Survey. https://www.usgs.gov/ news/usgs-tracks-how-hurricane-floodwaters-spread-nonnative-freshwater-plants-and-animals. Accessed 9 Oct 2018

O'Farrell MJ, Miller BW, Gannon WL (1999) Qualitative identification of free-flying bats using the Anabat detector. J Mammal 80(1):11-23

Office of Science and Technology Policy (2016a) Modernizing the regulatory system for biotechnology products: an update to the Coordinated Framework for the Regulation of Biotechnology. Washington, DC 
Office of Science and Technology Policy (2016b) National strategy for modernizing the regulatory system for biotechnology products. Washington, DC

Parker L (2015) How "crisis mapping" is shaping disaster relief in Nepal. Natl Geogr Mag https://news. nationalgeographic.com/2015/05/150501-nepal-crisismapping-disaster-relief-earthquake. Accessed 29 Aug 2018

Piaggio AJ, Segelbacher G, Seddon PJ, Alphey L, Bennett EL, Carlson RH, Friedman RM, Kanavy D, Phelan R, Redford KH, Rosales M, Slobodian L, Wheeler K (2017) Is it time for synthetic biodiversity conservation? Trends Ecol Evol 32:97-107. https://doi.org/10.1016/j.tree.2016.10.016

Pimentel D, Zuniga R, Morrison D (2005) Update on the environmental and economic costs associated with alien-invasive species in the United States. Ecol Econ 52:273-288. https://doi.org/10.1016/j.ecolecon.2004.10.002

Ramsey D (2012) UC San Diego students demonstrate smart camera trap at new engineering competition. UC San Diego News Cent. https://ucsdnews.ucsd.edu/index.php/ pressrelease/uc_san_diego_students_to_demonstrate_ smart_camera_trap_at_new_engineering_c. Accessed 2 Jul 2018

Reaser JK (2019) Putting a federal capacities assessment to work: blueprint for a national program for the early detection of and rapid response to invasive species (EDRR). Biol Invasions. https://doi.org/10.1007/s10530019-02177-5

Reaser JK, Waugh J (2007) Denying entry: opportunities to build capacity to prevent the introduction of invasive species and improve biosecurity at US ports. IUCN, Gland

Reaser JK, Burgiel SW, Kirkey J, Brantley KA, Veatch SD, Burgos-Rodríguez J (2019a) The early detection of and rapid response (EDRR) to invasive species: a conceptual framework and federal capacities assessment. Biol Invasions. https://doi.org/10.1007/s10530-019-02156-w

Reaser JK, Simpson A, Guala GF, Morisette JT, Fuller P (2019b) Envisioning a national invasive species information framework. Biol Invasions. https://doi.org/10.1007/ s10530-019-02141-3

Rees HA, Liu DR (2018) Base editing: precision chemistry on the genome and transcriptome of living cells. Nat Rev Genet 19:770-788. https://doi.org/10.1038/s41576-0180059-1

Reindl-Thompson SA, Shivik JA, Whitelaw A, Hurt A, Higgins K (2006) Efficacy of scent dogs in detecting black-footed ferrets at a reintroduction site in South Dakota. Wildl Soc Bull 34:1435-1439. https://doi.org/10.2193/00917648(2006)34\%5b1435:EOSDID\%5d2.0.CO;2

Reuter JA, Spacek DV, Snyder MP (2015) High-throughput sequencing technologies. Mol Cell 58:586-597. https:// doi.org/10.1016/j.molcel.2015.05.004

Roe AD, Torson AS, Bilodeau G, Bilodeau P, Blackburn GS et al (2018) Biosurveillance of forest insects: part I-integration and application of genomic tools to the surveillance of non-native forest insects. J Pest Sci 90:1-20

Roussel JM, Paillisson JM, Tréguier A, Petit E (2015) The downside of eDNA as a survey tool in water bodies. J Appl Ecol 52:823-826. https://doi.org/10.1111/1365-2664. 12428
Roy DP, Wulder MA, Loveland TR, Woodcock CE, Allen RG et al (2014a) Landsat-8: science and product vision for terrestrial global change research. Remote Sens Environ 145:154-172

Roy HE, Peyton J, Aldridge DC et al (2014b) Horizon scanning for invasive alien species with the potential to threaten biodiversity in Great Britain. Glob Chang Biol 20:3859-3871. https://doi.org/10.1111/gcb.12603

Sandino J, Gonzalez F, Mengersen K, Gaston KJ (2018) UAVs and machine learning revolutionising invasive grass and vegetation surveys in remote arid lands. Sens (Basel) 18:605. https://doi.org/10.3390/s18020605

Santana FS, Costa AHR, Truzzi FS, Silva FL, Santos SL, Francoy TM, Saraiva AM (2014) A reference process for automating bee species identification based on wing images and digital image processing. Ecol Inform 24:248-260. https://doi.org/10.1016/j.ecoinf.2013.12.001

Savidge JA, Stanford JW, Reed RN, Haddock GR, Yackel Adams AA (2011) Canine detection of free-ranging brown treesnakes on Guam. N Z J Ecol 35:174-181

Seebens H, Blackburn TM, Dyer E et al (2017) No saturation in the accumulation of alien species worldwide. Nat Commun 8:14435. https://doi.org/10.1038/ncomms14435

Selva D, Krejci D (2012) A survey and assessment of the capabilities of Cubesats for Earth observation. Acta Astronaut 74:50-68. https://doi.org/10.1016/j.actaastro. 2011.12.014

Servick K (2014) Eavesdropping on ecosystems. Science 343:834-837. https://doi.org/10.1126/science.343.6173. 834

Simberloff D (2003) Eradication-preventing invasions at the outset. Weed Sci 51:247-253

Simberloff D, Martin J-L, Genovesi P et al (2013) Impacts of biological invasions: what's what and the way forward. Trends Ecol Evol 28:58-66. https://doi.org/10.1016/j.tree. 2012.07.013

Sinkins SP, Gould F (2006) Gene drive systems for insect disease vectors. Nat Rev Genet 7:427-435. https://doi.org/10. $1038 /$ nrg 1870

Snow NP, Foster JA, VanNatta EH, Horak KE, Humphrys ST et al (2018) Potential secondary poisoning risks to nontargets from a sodium nitrite toxic bait for invasive wild pigs. Pest Manag Sci 74(1):181-188

Sollmann R, Linkie M, Haidir IA, Macdonald DW (2014) Bringing clarity to the clouded leopard Neofelis diardi : first density estimates from Sumatra. Oryx 48:536-539. https://doi.org/10.1017/S003060531400043X

Stockwell S, Gallo S (2017) Citizen science and wildlife conservation: lessons from 34 years of the Maine loon count. Maine Policy Review 26(2):25-32

Stowell D, Stylianou Y, Wood M., Pamuła H, Glotin H (2018) Automatic acoustic detection of birds through deep learning: the first Bird Audio Detection challenge. arXiv preprint arXiv:1807.05812

Strohecker L (2017) Drones help field crews find invasive species. Maui Invasive Species Committee Blog. http:// mauiinvasive.org/2017/11/22/drones. Accessed 2 Jul 2018

Suda J, Meyerson LA, Leitch IJ, Pysek P (2014) The hidden side of plant invasions: the role of genome size. New Phytol 205:994-1007 
Suiter K, Sferrazza S (2007) Monitoring the sale and trafficking of invasive vertebrate species using automated internet search and surveillance tools. In: Witmer WG, Pitt WC, Fagerston (eds) Managing vertebrate invasive species: proceedings of an international symposium. USDA/ APHIS/WS, National Wildlife Research Center, Fort Collins, CO

Sullivan BL, Aycrigg JL, Barry JH, Bonney RE, Bruns N et al (2014) The eBird enterprise: an integrated approach to development and application of citizen science. Biol Conserv 169:31-40

Sutherland WJ, Fleishman E, Mascia MB et al (2011) Methods for collaboratively identifying research priorities and emerging issues in science and policy. Methods Ecol Evol 2:238-247. https://doi.org/10.1111/j.2041-210X.2010. 00083. $\mathrm{x}$

Sutherland WJ, Bardsley S, Clout M et al (2013) A horizon scan of global conservation issues for 2013. Trends Ecol Evol 28:16-22. https://doi.org/10.1016/j.tree.2012.10.022

Swann DE, Kawanishi K, Palmer J (2010) Evaluating types and features of camera traps in ecological studies: a guide for researchers. In: O'Connell AF, Nichols JD, Karanth U (eds) Camera traps in animal ecology: methods and analyses. Springer, New York, pp 27-43

Swanson A, Kosmala M, Lintott C, Packer C (2016) A generalized approach for producing, quantifying, and validating citizen science data from wildlife images. Conserv Biol 30:520-531. https://doi.org/10.1111/cobi.12695

Taberlet P, Coissac E, Pompanon F, Brochmann C, Willerslev E (2012) Towards next-generation biodiversity assessment using DNA metabarcoding. Mol Ecol 21:2045-2050. https://doi.org/10.1111/j.1365-294X.2012.05470.x

Takahashi TT (2012) Drones and privacy. Colum Sci Tech L Rev 14:72-114

TerraDaily (2018) Montana state laser technology could help Yellowstone battle invasive trout. TerraDaily. http://www. terradaily.com/reports/Montana_State_laser_technology_ could_help_Yellowstone_battle_invasive_trout_999.html. Accessed 2 Jul 2018

Thomsen PF, Willerslev E (2015) Environmental DNA: an emerging tool in conservation for monitoring past and present biodiversity. Biol Conserv 183:4-18. https://doi. org/10.1016/j.biocon.2014.11.019

Titze-de-Almeida R, David C, Titze-de-Almeida SS (2017) The race of 10 synthetic RNAi-based drugs to the pharmaceutical market. Pharm Res 34:1339-1363. https://doi.org/10. 1007/s11095-017-2134-2

Unsicker SB, Kunert G, Gershenzon J (2009) Protective perfumes: the role of vegetative volatiles in plant defense against herbivores. Curr Opin Plant Biol 12:479-485. https://doi.org/10.1016/j.pbi.2009.04.001

US Coast Guard (2015) Vessel biofouling prevention and management options report. Report No. CG-D-15-15. US Department of Homeland Security, US Coast Guard, Acquisition Directorate Research \& Development Center, Washington, DC

Van Horn G, Mac Aodha O, Song Y, Shepard A, Adam H, Perona P, Belongie S (2018) The iNaturalist classification and detection dataset https://vision.cornell.edu/se3/wpcontent/uploads/2018/03/1916.pdf. Accessed 29 Sep 2018 van Putten I, Cvitanovic C, Fulton E, Lacey J, Kelly R (2018) The emergence of social license necessitates reforms in environmental regulation. Ecol Soc 23(3):24. https://doi. org/10.5751/ES-10397-230324

Vice DS, Vice DL (2004) Characteristics of brown treesnakes Boiga irregularis removed from Guam's transportation network. Pacific Conserv Biol 10:216-220

Walker T, Johnson PH, Moreira LA, Iturbe-Ormaetxe I, Frentiu FD, McMeniman CJ (2011) The wMel Wolbachia strain blocks dengue and invades caged Aedes aegypti populations. Nature 476:450-455. https://doi.org/10.1038/ nature 10355

Wallace RD, Bargeron IV CT, Reaser JK (2019) Enabling decisions that make a difference: guidance for improving access to and analysis of invasive species information. Biol Invasions. https://doi.org/10.1007/s10530-019-02142-2

Werden L, Vincent J, Tanner J, Ditmer M (2015) Not quite free yet: clarifying UAV regulatory progress for ecologists. Front Ecol Environ 13:533-534. https://doi.org/10.1890/ 15.WB. 018

Wilson AD (2013) Diverse applications of electronic-nose technologies in agriculture and forestry. Sensors (Switzerland) 13:2295-2348. https://doi.org/10.3390/ s130202295

Wilson AD, Lester DG, Oberle CS (2004) Development of conductive polymer analysis for the rapid detection and identification of phytopathogenic microbes. Phytopathol 94(5):419-431

Wing MG, Bettinger P (2008) Geographic information systems: applications in natural resource management. Oxford University Press, New York

Winskill P, Carvalho DO, Capurro ML, Alphey L, Donnelly CA, McKemey AR (2015) Dispersal of engineered male Aedes aegypti mosquitoes. PLoS Negl Trop Dis 9:1-18. https://doi.org/10.1371/journal.pntd.0004156

Wittenberg R, Cock MJW (eds) (2001) Invasive alien species: a toolkit of best prevention and management practices. Centre for Agriculture and Bioscience International International, Wallingford, Oxon

Wu Y, Trepanowski NF, Molongoski JJ, Peter FR (2017) Identification of wood-boring beetles (Cerambycidae and Buprestidae) intercepted in trade associated solid wood packaging material using DNA barcoding and morphology. Sci Rep 7:40316. https://doi.org/10.1038/srep40316

Xiao Y, Greiner R, Lewis MA (2018) Evaluation of machine learning methods for predicting eradication of aquatic invasive species. Biol Invasions. https://doi.org/10.1007/ s10530-018-1715-2

Ye YH, Carrasco AM, Frentiu FD, Chenoweth SF, Beebe NW, van den Hurk AF, Simmons CP, O’Neill SL (2015) Wolbachia reduces the transmission potential of dengue-infected Aedes aegypti. PLoS Negl Trop Dis 9:1-19. https:// doi.org/10.1371/journal.pntd.0003894

Young HS, Parker IM, Gilbert GS et al (2017) Introduced Species, disease ecology, and biodiversity-disease relationships. Trends Ecol Evol 32:41-54. https://doi.org/10. 1016/j.tree.2016.09.008

Yuzvik A, Kelly BR, Lombardi JP, Uvarov NA, Godsey WG (2018) Major qualifying projects. Worcester Polytechnic Institute \#2499. https://digitalcommons.wpi.edu/mqp-all/ 2499. Accessed 9 Oct 2018 
Zorović M, Čokl A (2014) Laser vibrometry as a diagnostic tool for detecting wood-boring beetle larvae. J Pest Sci 88(1):107-112. https://doi.org/10.1007/s10340-014-05675

Zotti M, dos Santos EA, Cagliari D et al (2018) RNA interference technology in crop protection against arthropod pests, pathogens and nematodes. Pest Manag Sci 74:1239-1250. https://doi.org/10.1002/ps.4813

Publisher's Note Springer Nature remains neutral with regard to jurisdictional claims in published maps and institutional affiliations. 